\title{
The Irreversibility Premium
}

\author{
ROBERT S. CHIRINKO \\ HUNTLEY SCHALLER
}

CESIFO WORKING PAPER NO. 2265

CAtegory 5: Fiscal Policy, MaCroeconomics AND Growth MARCH 2008

An electronic version of the paper may be downloaded

- from the SSRN website:

- from the RePEc website:

- from the CESifo website:

www.SSRN.com

Www.RePEc.org

www.CESifo-group.org/wp 
CESifo Working Paper No. 2265

\title{
The Irreversibility Premium
}

\begin{abstract}
When investment is irreversible, theory suggests that firms will be "reluctant to invest." This reluctance creates a wedge between the discount rate guiding investment decisions and the standard Jorgensonian user cost (adjusted for risk). We use the intertemporal tradeoff between the benefits and costs of changing the capital stock to estimate this wedge, which we label the irreversibility premium. Estimates are based on panel data for the period 1980-2001. The large dataset allows us to estimate the effects of limited resale markets, low depreciation rates, high uncertainty, and negative industry-wide shocks on the irreversibility premium. Our estimates provide a readily interpretable measure of the importance of irreversibility and document that the irreversibility premium is both economically and statistically significant.
\end{abstract}

JEL Code: E22, E32.

Keywords: irreversibility, investment, non-convex adjustment costs.

\author{
Robert S. Chirinko \\ Department of Finance \\ University of Illinois at Chicago \\ 2421 University Hall \\ 601 South Morgan (MC 168) \\ Chicago, Illinois 60607-7121 \\ USA \\ chirinko@uic.edu
}

\author{
Huntley Schaller \\ Department of Economics \\ Carleton University \\ 1125 Colonel By Drive \\ Ottawa, Ontario K1S 5B6 \\ Canada \\ schaller@ccs.carleton.ca
}

February 2008

We thank participants at the American Economic Association (especially J. Eberly), the City University conference (London) on New Perspectives On Fixed Investment (especially V. Ghosal), T2M conference (Paris) on Theories and Methods in Macroeconomics (especially F. Guerrero), MIT, and the University of Illinois (Chicago) and two anonymous referees, N. Bloom, C. Cummins, H. Dezhbakhsh, C. Ehreman, S. Fazzari, L. Guiso, C. Pollack, V. Ramey, and K. Whelan for many helpful comments and suggestions. Chirinko thanks the Center For Economic Studies (Munich) for financial support under its Visiting Scholar Program; Schaller thanks the Economics Department at MIT for providing an excellent environment in which to carry out a substantial part this research and the SSHRC for financial support. All errors, omissions, and conclusions remain the sole responsibility of the authors. 


\section{The Irreversibility Premium}

\section{Table of contents}

1. Introduction

2. Prior empirical studies

3. Optimal investment

1. The intertemporal tradeoff

2. Frictions and the irreversibility premium

3. Non-positive investment in period $t$

4. From theory to estimation

1. Specification issues

2. Panel dataset

5. Tests of competing models

6. Estimates of the irreversibility premium

1. Characteristics that affect the irreversibility premium

1. Limited resale markets

2. Low depreciation rates

3. Uncertainty

4. Negative industry-wide shocks

2. Combinations of two characteristics that affect the irreversibility premium

1. Limited resale markets

2. Low depreciation rates

3. Uncertainty

3. Multiple combinations of variables that affect the irreversibility premium

7. Irreversibility and finance constraints

8. Investment regimes

9. Summary and conclusions

References

Data appendix

Tables 


\section{Introduction}

How important is investment irreversibility? When capital goods are highly specialized or industry specific, firms may find that reversing an investment decision is impossible or, more generally, costly because of a differential between the purchase price and resale price of the capital good or because of fixed costs from disinvesting. Much theoretical work has examined the impact of completely or partly irreversible investment on firm behavior. (Among other studies, see Bernanke (1983), Abel and Eberly (1994), Bertola and Caballero (1994), and Dixit and Pindyck (1994), as well as the earlier work of Arrow (1968) and Nickell (1978) and the survey by Caballero (1999).) The fundamental result is that irreversibility generates a "reluctance to invest," as a forward-looking firm hesitates to invest today because of the possibility that it may wish to sell capital in the uncertain future but will be able to reclaim little if any of the undepreciated value.

The impact of irreversibility - or, more generally, non-convex adjustment costs - has been assessed in several empirical studies discussed below. ${ }^{1}$ This paper takes a new approach to assessing the impact of irreversibility by focusing on the intertemporal pattern of investment. The "reluctance to invest" result can be characterized by a wedge between the discount rate that guides investment decisions and the Jorgensonian user cost of capital (adjusted for risk). Irreversibility constraints force the firm to use a discount rate higher than the risk-adjusted market discount rate. This wedge between effective and market discount rates is the "irreversibility premium." As part of the discount rate, it affects the intertemporal tradeoff between the costs and benefits of adjusting the capital stock. We use the intertemporal tradeoff to estimate the irreversibility premium. Our approach focuses on the fundamental theoretical implication of irreversibility and provides a readily interpretable measure of the economic importance of irreversibility constraints.

We derive the irreversibility premium and our empirical specification from the optimality conditions for investment. Our analysis is based on the investment model of Abel and Eberly (1994), which encompasses a variety of frictions that have been prominent in the investment

\footnotetext{
${ }^{1}$ Throughout the paper, we use "irreversible" to refer to either complete or partial irreversibility that results in unrecoverable sunk costs. The theoretical model and estimating equation allow for the more general case of partial irreversibility (which includes complete irreversibility as a special case when the resale value of capital is zero), as well as fixed costs.
} 
literature - irreversibility (or, more precisely, costly reversibility), convex adjustment costs, and fixed costs. We extract the testable implications associated with the Abel-Eberly model for the discount rate that appears in the Euler equation for capital.

We begin by showing how the convex adjustment cost model is nested within the nonconvex adjustment cost model as a special case where the purchase and resale prices of capital goods are equal and there are no fixed costs of adjusting the capital stock. We derive the Euler equation for the convex adjustment cost model and show how terms involving the price of capital goods, marginal adjustment costs, the irreversibility premium, and an indicator variable for a high probability of facing a binding irreversibility constrain will all enter the error term of the Euler equation for the convex adjustment cost model if there are non-convex adjustment costs in the data. This yields a series of three tests between the convex and non-convex adjustment cost models, based on the overidentifying restrictions for the convex and non-convex adjustment cost models. First, for the full sample, the data reject the convex adjustment cost model. Second, for a subsample of observations where non-convex adjustment costs are unlikely to be important, the test of overidentifying restrictions fails to reject the convex adjustment cost model. Third, the test of overidentifying restrictions fails to reject the non-convex adjustment cost model (for the full sample). These three results provide evidence for the importance of nonconvex adjustment costs.

We then move to our main contribution, which is to estimate the irreversibility premium. We estimate the Euler equation for capital and allow the intertemporal pattern of investment spending to reveal what discount rate firms are using. We calculate the irreversibility premium by estimating the difference in risk-adjusted discount rates between observations where firms are more likely to face binding irreversibility constraints and the rest of the observations in our dataset.

Economic theory suggests a number of factors that should determine the importance of irreversibility: limited resale markets, low depreciation, high uncertainty, and negative industrywide shocks. Irreversibility arises when it is costly for firms to dispose of used capital. The estimated irreversibility premium for firms with limited resale markets is 510 basis points, using an approach to measuring limited resale markets based on Shleifer and Vishny's (1992) analysis of liquidation values. Low depreciation rates make it more difficult for firms to shed unwanted capital and therefore more likely that they will bump up against the irreversibility constraint. 
The estimated irreversibility premium for firms with low depreciation rates is 220 basis points. Previous theoretical work suggests that the irreversibility premium is increasing in the degree of uncertainty. The estimated irreversibility premium for firms with a high degree of uncertainty (about demand for their products) is 730 basis points. Unfavorable shocks tend to push firms towards the irreversibility constraint, and it may be more difficult for firms to dispose of capital goods when a negative shock affects the industry as a whole. The estimated irreversibility premium for observations when there has been a recent negative industry-wide shock is 550 basis points. For each of these characteristics, the estimated irreversibility premium is significantly different from zero.

Even though it faces, for example, limited resale markets, a firm might be unlikely to encounter a binding irreversibility constraint if its industry is doing well or it has a high depreciation rate. We therefore examine the interaction between characteristics that affect the probability and cost of irreversibility. When a firm has a low depreciation rate and high cost uncertainty, the estimated irreversibility premium is 920 basis points. The estimated irreversibility premium for firms with limited resale markets and high demand uncertainty is 1080 basis points. For firms with a low depreciation rate that have suffered recent negative industry-wide shocks, the estimated irreversibility premium is 1260 basis points.

The paper is organized as follows. Section 2 contains a review of several empirical approaches to assessing the impact of irreversibility and some previous papers that have estimated investment Euler equations. Section 3 derives the irreversibility premium and our empirical specification from the conditions for optimal behavior and relates the irreversibility premium to the probability and cost of facing binding irreversibility constraints. Section 4 briefly describes auxiliary assumptions required for estimation (e.g., rational expectations), and discusses our panel dataset, which covers the period 1980-2001. Section 5 derives the convex adjustment cost model as a special case of the model in Section 3 and presents tests of the convex and non-convex adjustment cost models. Section 6 reports estimates of the irreversibility premium. Section 7 examines whether non-convex adjustment costs, finance constraints, or both affect the discount rate. Section 8 tests whether the non-convex adjustment cost model provides a good fit to the data in the three investment regimes in the model - positive investment, zero investment, and negative investment. Section 9 offers a brief conclusion and discusses some implications of our findings. 


\section{Prior empirical studies}

The impact of irreversibility has been examined in several studies using a variety of approaches. One set of studies focuses on the current level of investment expenditures. Caballero, Engel, and Haltiwanger (1995, U.S. plant data) and Goolsbee and Gross (1997, airplane data) show that the adjustment rate of investment is asymmetric, being much larger for expanding than contracting plants or airlines. These results are consistent with irreversibility constraints and at odds with the familiar convex adjustment cost model. Abel and Eberly (1996a, U.S. firm data), Eberly (1997, firm data for 11 industrialized countries), Caballero and Engel (1999, U.S. two-digit industry data), Cooper and Haltiwanger (2006, U.S. plant data), and Bloom (2007, U.S. firm data) find that the addition of non-convex adjustment costs to a model with convex adjustment costs significantly improves the fit. A negative relation between investment and uncertainty is consistent with the presence of important irreversibility effects and has been reported by Leahy and Whited (1996, U.S. firm data) and Ghosal and Loungani (2000, U.S. industry data). Guiso and Parigi (1999, Italian firm data) also find that investment is negatively related to uncertainty and that this effect is greater for firms that cannot easily reverse their investment decisions because of limited resale markets for capital goods. ${ }^{2}$ Bloom, Bond, and van Reenen (2007, UK firm data) examine the effect of non-convex adjustment costs on the responsiveness of investment. They find that higher uncertainty reduces the responsiveness of investment to demand shocks -- and that these "cautionary effects" are large. Barnett and Sakellaris (1998, U.S. firm data) examine the sensitivity of investment to Tobin's Q over different regimes defined by Q. They document differential sensitivity across three regimes but, in contrast to the irreversibility model of Abel and Eberly (1994), do not find that the sensitivity is lower in the regime where Q equals its long-run equilibrium value of unity. Abel and Eberly (1996a) show that this result could be consistent with their model when it includes heterogeneous capital goods.

The importance of irreversibility has been assessed in several other studies that do not

\footnotetext{
${ }^{2}$ The negative relation between uncertainty and investment has been reported for other countries: Belgium, Butzen, Fuss, and Vermeulen (2003); Germany, von Kalckreuth (2003); the Netherlands, Bo, Lensink, and Sterken (2001); United Kingdom, Temple, Urga, and Driver (2001).
} 
focus on investment expenditures. ${ }^{3}$ Pindyck and Soliamanos (1993, aggregate data for 30 countries) and Caballero and Pindyck (1996, U.S. industry data) estimate the relationship between proxies for the investment threshold and variables such as the volatility of the marginal product of capital, reporting results consistent with irreversibility. Studying capital allocation in the depressed U.S. aerospace industry, Ramey and Shapiro (2001) find that, on average, the market value of used assets is only $30 \%$ of the estimated replacement cost of new equipment (adjusted for depreciation). Asplund (2000) reports a comparable statistic of 50\% based on salvage values of metalworking machinery in Sweden.

In addition to studies that examine the importance of irreversibility, another strand of the literature that is relevant to our paper is prior empirical estimates of investment Euler equations. Shapiro (1986) and Whited (1992) were pioneering studies. Shapiro (1986) was one of the first to estimate the first-order condition for investment (Euler equation), rather than a closed-form decision rule, such as a Q investment equation. Whited (1992) showed how investment Euler equations could be used to test for finance constraints. Her paper is part of a substantial literature that includes Hubbard and Kashyap (1992), Bond and Meghir (1994), Hubbard, Kashyap, and Whited (1995), Ng and Schaller (1996), Whited (1998), Love (2003), Chirinko and Schaller (2004a), and Whited and Wu (2006). Whited (1998) is particularly relevant, because it uses the investment Euler equation to examine whether the standard convex adjustment cost model fits the data and finds evidence against the model. We return to this point in Section 5, where we use a similar approach (based on overidentifying restrictions) to test the convex adjustment cost model and find evidence consistent with Whited (1998).

\section{Optimal investment}

This section derives the irreversibility premium and our empirical specification from the optimality conditions for the firm's investment problem. We use the Abel and Eberly (1994) model as a point of departure. The Abel-Eberly model encompasses a variety of frictions,

\footnotetext{
${ }^{3}$ The relation between the capital stock and irreversibility is ambiguous. When there are irreversibility constraint, a firm faces a "user cost effect" (i.e., a positive irreversibility premium) that has a negative impact on the desired capital stock. But it also faces a "hangover effect" reflecting that firms will occasionally have more capital than is desired and the irreversibility constraint will prevent them from making the appropriate reduction. Thus, the observed capital stock can be higher or lower in the face of irreversibility constraints (Abel and Eberly (1999); Caballero (1999)).
} 
including costly reversibility, convex adjustment costs, and fixed costs of changing the capital stock. ${ }^{4}$ Equation (16) expresses the intertemporal tradeoff that we use to estimate the irreversibility premium. Readers with less immediate interest in the derivations are encouraged to proceed to Section 3.2., which offers an intuitive explanation of the intertemporal tradeoff and describes our strategy for identifying the irreversibility premium.

Central to the study of non-convex adjustment costs is that the optimal level of investment can be positive, zero, or negative. The positive investment regime has been analyzed extensively in the convex adjustment cost literature, and we begin with this familiar model in Sections 3.1 and 3.2. With this benchmark established, we then proceed to develop an econometric model appropriate to the non-positive investment regimes in Section 3.3.

\subsection{The intertemporal tradeoff}

The risk-neutral firm selects policies to maximize its expected present value of profits in the face of four constraints. First, output is determined by a technology depending on capital $(\mathrm{K})$, a vector of variable factors of production, and a stochastic technology shock ( $\varepsilon$, which can also represent stochastic shocks to the demand schedule or to prices of the variable factors). Second, $\varepsilon$ is a diffusion process evolving according to the following equation (time subscripts have been suppressed),

$$
\mathrm{d} \varepsilon=\mu[\varepsilon] \mathrm{dt}+\sigma[\varepsilon] \mathrm{dz}
$$

where $\mu[\varepsilon]$ is the drift term, $\sigma[\varepsilon]$ is the instantaneous variance, and $\mathrm{z}$ is a standard Weiner process. Third, capital depreciates geometrically at rate $\delta$, and evolves according to the following equation,

$$
\mathrm{dK}=(\mathrm{I}-\delta \mathrm{K}) \mathrm{dt}
$$

where $\mathrm{I}$ is the investment rate.

\footnotetext{
${ }^{4}$ Other models (such as Bertola and Caballero (1994) and Dixit and Pindyck (1994)) are likely to yield a corresponding irreversibility premium. For example, in equations (10) and (11) in Bertola and Caballero, the expression $1 / 2 \Sigma^{2} \mathrm{~A}$ corresponds to the irreversibility premium $\theta$ derived below.
} 
Fourth, the firm is constrained by an augmented adjustment cost function, $\mathrm{C}[\mathrm{I}, \mathrm{K}]$, that distinguishes between regimes where investment is positive, negative, or zero. The function $\mathrm{C}[\mathrm{I}, \mathrm{K}]$ is differentiable for all $\mathrm{I}$, except at $\mathrm{I}=0$. (There are two independent sources of nondifferentiability at zero: a difference between purchase and resale prices and fixed costs.) To identify these different regimes in the optimization problem, we define the following indicator variables,

$$
\begin{aligned}
& \mathrm{v}^{+}=1 \quad \text { if } \mathrm{I}>0,0 \text { otherwise, } \\
& \mathrm{v}^{-}=1 \quad \text { if } \mathrm{I}<0,0 \text { otherwise, } \\
& \mathrm{v}^{0}=1 \quad \text { if } \mathrm{I}=0,0 \text { otherwise. }
\end{aligned}
$$

Note that the three regimes are mutual exclusive and exhaustive. To reflect the partly irreversible nature of investment, we distinguish between the prices at which the firm can purchase $\left(\mathrm{p}^{+}\right)$and resell $\left(\mathrm{p}^{-}\right)$a unit of uninstalled capital, where $\mathrm{p}^{+} \geq \mathrm{p}^{-} \geq 0$. If $\mathrm{p}^{-}=0$, investment is completely irreversible; if $\mathrm{p}^{+}=\mathrm{p}^{-}$, investment is completely reversible. Additionally, whenever investing or disinvesting, the firm incurs convex adjustment costs, $\mathrm{G}[\mathrm{I}, \mathrm{K}]$. As is standard in the literature, $\mathrm{G}[0, \mathrm{~K}]=\mathrm{G}_{\mathrm{I}}[0, \mathrm{~K}]=\mathrm{G}_{\mathrm{K}}[0, \mathrm{~K}]=0$. Lastly, the firm faces fixed costs, $\mathrm{F}$, whenever investing or disinvesting. The augmented adjustment cost function is specified as follows,

$$
C[I, K]=v^{+} p^{+} I+v^{-} p^{-} I+G[I, K]+\left(1-v^{0}\right) F .
$$

Given these four constraints, value maximizing behavior generates two conditions describing the optimal paths for investment and capital that are useful in deriving our econometric equation. When the firm is investing or disinvesting in period $t$, the marginal value of a unit of installed capital in period $t\left(q_{t}\right)$ equals the marginal adjustment costs $\left(C_{I}\left[I_{t}, K_{t}\right]\right)$,

$$
\begin{aligned}
\mathrm{q}_{\mathrm{t}}=\mathrm{C}_{\mathrm{I}}\left[\mathrm{I}_{\mathrm{t}}, \mathrm{K}_{\mathrm{t}}\right]=\mathrm{v}^{+} \mathrm{p}^{+}{ }_{\mathrm{t}}^{+}+\mathrm{v}^{-}{ }_{\mathrm{t}}^{-} \mathrm{p}_{\mathrm{t}}^{-}+\mathrm{G}_{\mathrm{I}}\left[\mathrm{I}_{\mathrm{t}}, \mathrm{K}_{\mathrm{t}}\right], \\
\mathrm{q}_{\mathrm{t}}>\mathrm{q}^{+} \leftrightarrow \mathrm{I}_{\mathrm{t}}>0 \leftrightarrow \mathrm{v}^{+}{ }_{\mathrm{t}}=1, \\
\mathrm{q}_{\mathrm{t}}<\mathrm{q}^{-} \leftrightarrow \mathrm{I}_{\mathrm{t}}<0 \leftrightarrow \mathrm{v}_{\mathrm{t}}^{-}=1,
\end{aligned}
$$


where $\mathrm{q}^{+}$and $\mathrm{q}^{-}$are the threshold values that depend only on the augmented adjustment cost technology and $\mathrm{K}_{\mathrm{t}}$ is the beginning-of-period capital stock. As shown by equations (6a) and (6b), whether a firm is in a positive or negative investment regime is determined by the value of q relative to these two thresholds. Note that equation (5) does not apply to the zero investment regime. When $\mathrm{q}_{\mathrm{t}}$ lies between the threshold values, $\mathrm{q}^{-} \leq \mathrm{q}_{\mathrm{t}} \leq \mathrm{q}^{+}$, the firm is in the "zone of inaction," and optimal investment is zero. For ease of exposition, we will initially focus on positive investment in period $\mathrm{t}$, returning to the case of zero and negative investment in period $\mathrm{t}$ in Section 3.3 below.

Value maximizing behavior also generates the following one-period return relation (Abel and Eberly, 1994, equation 19) obtained by differentiating the Bellman equation with respect to the capital stock,

$$
\left(\mathrm{r}_{\mathrm{t}}+\delta\right) \mathrm{q}_{\mathrm{t}}=\pi_{\mathrm{K}}\left[\mathrm{I}_{\mathrm{t}}, \mathrm{K}_{\mathrm{t}}, \varepsilon_{\mathrm{t}}\right]+\mathrm{E}\left\{\mathrm{dq}_{\mathrm{t}}\right\} / \mathrm{dt},
$$

where $\mathrm{r}_{\mathrm{t}}$ is the market discount rate (adjusted for systematic risk, inflation, and taxes), $\mathrm{E}\{$.$\} is the$ expectation operator, and $\pi_{\mathrm{K}}\left[\mathrm{I}_{t}, \mathrm{~K}_{\mathrm{t}}, \varepsilon_{\mathrm{t}}\right]$ is the marginal revenue product of capital. The latter term includes both the increment to production and the decrement to convex adjustment costs $\left(\mathrm{G}_{\mathrm{K}}\left[\mathrm{I}_{\mathrm{t}}, \mathrm{K}_{\mathrm{t}}\right]\right)$, and reflects optimal choices of variable factors and investment. The left side of equation (7) is the required return on a marginal unit of capital, and is equated to capital's expected return, the incremental profit plus expected capital gain. Defining $\left(\mathrm{q}_{\mathrm{t}+1}-\mathrm{q}_{\mathrm{t}}\right) \equiv d \mathrm{q}_{\mathrm{t}}$ and $\pi_{\mathrm{K}, \mathrm{t}} \equiv \pi_{\mathrm{K}}\left[\mathrm{I}_{\mathrm{t}}, \mathrm{K}_{\mathrm{t}}, \varepsilon_{\mathrm{t}}\right]$ and assuming that expectations are formed with information available in period $\mathrm{t}, \mathrm{E}\{.\} \equiv \mathrm{E}_{\mathrm{t}}\{$.$\} , we rewrite equation (7) as follows,$

$$
-\mathrm{q}_{\mathrm{t}}\left(1+\mathrm{r}_{\mathrm{t}}+\delta\right)+\left(\pi_{\mathrm{K}, \mathrm{t}}+\mathrm{E}_{\mathrm{t}}\left\{\mathrm{q}_{\mathrm{t}+1}\right\}\right)=0,
$$

which has the form of a standard Euler equation appearing frequently in the investment literature.

In order for equation (8) to be estimable, we need to relate the $\mathrm{q}_{\mathrm{t}}$ and $\mathrm{E}_{\mathrm{t}}\left\{\mathrm{q}_{\mathrm{t}+1}\right\}$ terms to observable variables. Since in this section we are focusing on the positive investment regime in period $t, q_{t}$ can be written in terms of observables using equation (5), 


$$
\mathrm{q}_{\mathrm{t}}=\mathrm{p}_{\mathrm{t}}^{+}+\mathrm{G}_{\mathrm{I}}\left[\mathrm{I}_{\mathrm{t}}, \mathrm{K}_{\mathrm{t}}\right]
$$

The analysis of $E_{t}\left\{q_{t+1}\right\}$ is more complicated. We begin by taking the expectation of $q_{t+1}$ for period $\mathrm{t}+1$ conditional on period $\mathrm{t}$ information, and form the following set of conditional expectations for the three investment regimes,

$$
\mathrm{E}_{\mathrm{t}}\left\{\mathrm{q}_{\mathrm{t}+1}\right\}=\mathrm{h}^{+}{ }_{\mathrm{t}+1} \mathrm{E}_{\mathrm{t}}\left\{\mathrm{q}_{\mathrm{t}+1}: \mathrm{v}^{+}{ }_{\mathrm{t}+1}\right\}+\mathrm{h}^{-}{ }_{\mathrm{t}+1} \mathrm{E}_{\mathrm{t}}\left\{\mathrm{q}_{\mathrm{t}+1}: \mathrm{v}_{\mathrm{t}+1}^{-}\right\}+\mathrm{h}_{\mathrm{t}+1}^{0} \mathrm{E}_{\mathrm{t}}\left\{\mathrm{q}_{\mathrm{t}+1}: \mathrm{v}_{\mathrm{t}+1}^{0}\right\},
$$

where $\mathrm{h}_{\mathrm{t}+1}^{+}$is the probability of being in the positive investment regime in period $\mathrm{t}+1$ and $\mathrm{v}_{t+1}^{+}$is the indicator variable equal to one if investment is positive in period $t+1$. Similar definitions apply to $\left(\mathrm{h}^{-}{ }_{t+1}, \mathrm{v}^{-}{ }_{\mathrm{t}+1}\right)$ and $\left(\mathrm{h}_{\mathrm{t}+1}^{0}, \mathrm{v}_{\mathrm{t}+1}^{0}\right)$. The first two terms in equation (10) pertain to the positive and negative investment regimes, respectively, and contain unobservable $\mathrm{q}_{\mathrm{t}+1}$ 's. We eliminate these unobservable variables by advancing the terms in equation (5) by one period and substituting for the $\mathrm{q}_{\mathrm{t}+1}$ 's in $\mathrm{E}_{\mathrm{t}}\left\{\mathrm{q}_{\mathrm{t}+1}: \mathrm{v}^{+}{ }_{\mathrm{t}+1}\right\}$ and $\mathrm{E}_{\mathrm{t}}\left\{\mathrm{q}_{\mathrm{t}+1}: \mathrm{v}^{-}{ }_{\mathrm{t}+1}\right\}$,

$$
\begin{aligned}
\mathrm{E}_{\mathrm{t}}\left\{\mathrm{q}_{\mathrm{t}+1}\right\} & =\mathrm{h}^{+}{ }_{\mathrm{t}+1} \mathrm{E}_{\mathrm{t}}\left\{\mathrm{p}^{+}{ }_{\mathrm{t}+1}: \mathrm{v}^{+}{ }_{\mathrm{t}+1}\right\}+\mathrm{h}^{-}{ }_{\mathrm{t}+1} \mathrm{E}_{\mathrm{t}}\left\{\mathrm{p}_{\mathrm{t}+1}^{-}: \mathrm{v}^{-}{ }_{\mathrm{t}+1}\right\} \\
& +\mathrm{h}^{+}{ }_{\mathrm{t}+1} \mathrm{E}_{\mathrm{t}}\left\{\mathrm{G}_{\mathrm{I}}\left[\mathrm{I}_{\mathrm{t}+1}, \mathrm{~K}_{\mathrm{t}+1}\right]: \mathrm{v}^{+}{ }_{\mathrm{t}+1}\right\}+\mathrm{h}^{-}{ }_{\mathrm{t}+1} \mathrm{E}_{\mathrm{t}}\left\{\mathrm{G}_{\mathrm{I}}\left[\mathrm{I}_{\mathrm{t}+1}, \mathrm{~K}_{\mathrm{t}+1}\right]: \mathrm{v}^{-}{ }_{\mathrm{t}+1}\right\} \\
& +\mathrm{h}_{\mathrm{t}+1}^{0} \mathrm{E}_{\mathrm{t}}\left\{\mathrm{q}_{\mathrm{t}+1}: \mathrm{v}_{\mathrm{t}+1}^{0}\right\} .
\end{aligned}
$$

Adding and subtracting the following two terms -- $\mathrm{h}^{-}{ }_{\mathrm{t}+1} \mathrm{E}_{\mathrm{t}}\left\{\mathrm{p}^{+}{ }_{\mathrm{t}+1}: \mathrm{v}^{-}{ }_{\mathrm{t}+1}\right\}$ and $\mathrm{h}^{0}{ }_{\mathrm{t}+1} \mathrm{E}_{\mathrm{t}}\left\{\mathrm{p}^{+}{ }_{\mathrm{t}+1}: \mathrm{v}_{\mathrm{t}+1}^{0}\right\}$-- to equation (11) and rearranging, we obtain,

$$
\begin{aligned}
\mathrm{E}_{\mathrm{t}}\left\{\mathrm{q}_{\mathrm{t}+1}\right\} & =\mathrm{h}_{\mathrm{t}+1}^{+} \mathrm{E}_{\mathrm{t}}\left\{\mathrm{p}^{+}{ }_{\mathrm{t}+1}: \mathrm{v}^{+}{ }_{\mathrm{t}+1}\right\}+\mathrm{h}^{-}{ }_{\mathrm{t}+1} \mathrm{E}_{\mathrm{t}}\left\{\mathrm{p}_{\mathrm{t}+1}^{+}: \mathrm{v}_{\mathrm{t}+1}^{-}\right\}+\mathrm{h}^{0}{ }_{\mathrm{t}+1} \mathrm{E}_{\mathrm{t}}\left\{\mathrm{p}_{\mathrm{t}+1}^{+}: \mathrm{v}_{\mathrm{t}+1}^{0}\right\} \\
& +\mathrm{h}_{\mathrm{t}+1}^{+} \mathrm{E}_{\mathrm{t}}\left\{\mathrm{G}_{\mathrm{I}}\left[\mathrm{I}_{\mathrm{t}+1}, \mathrm{~K}_{\mathrm{t}+1}\right]: \mathrm{v}^{+}{ }_{\mathrm{t}+1}\right\}+\mathrm{h}_{\mathrm{t}+1}^{-} \mathrm{E}_{\mathrm{t}}\left\{\mathrm{G}_{\mathrm{I}}\left[\mathrm{I}_{\mathrm{t}+1}, \mathrm{~K}_{\mathrm{t}+1}\right]: \mathrm{v}_{\mathrm{t}+1}^{-}\right\} \\
& +\mathrm{h}_{\mathrm{t}+1}^{-} \mathrm{E}_{\mathrm{t}}\left\{\mathrm{p}_{\mathrm{t}+1}^{-}-\mathrm{p}_{\mathrm{t}+1}^{+}: \mathrm{v}_{\mathrm{t}+1}^{-}\right\} \\
& +\mathrm{h}_{\mathrm{t}+1}^{0} \mathrm{E}_{\mathrm{t}}\left\{\mathrm{q}_{\mathrm{t}+1}-\mathrm{p}_{\mathrm{t}+1}^{+}: \mathrm{v}_{\mathrm{t}+1}^{0}\right\}
\end{aligned}
$$

The first line in equation (12) is the unconditional expectation of the purchase price of capital, $\mathrm{E}_{\mathrm{t}}\left\{\mathrm{p}^{+}{ }_{\mathrm{t}+1}\right\}$. In the zero investment regime, $\mathrm{G}_{\mathrm{I}}\left[0, \mathrm{~K}_{\mathrm{t}+1}\right]=0$ and $\mathrm{E}_{\mathrm{t}}\left\{\mathrm{G}_{\mathrm{I}}\left[0, \mathrm{~K}_{\mathrm{t}+1}\right]: \mathrm{v}^{0}{ }_{\mathrm{t}+1}\right\}=0$; hence the second line in equation (12) represents the unconditional expectation of marginal adjustment 
costs, $E_{t}\left\{G_{I}\left[I_{t+1}, K_{t+1}\right]\right\}$. We represent the remaining two terms in equation (12) by $\eta_{t}$, which will be discussed in the next subsection, and rewrite equation (12) as follows,

$$
\begin{aligned}
& \mathrm{E}_{\mathrm{t}}\left\{\mathrm{q}_{\mathrm{t}+1}\right\}=\mathrm{E}_{\mathrm{t}}\left\{\mathrm{p}_{\mathrm{t}+1}^{+}\right\}+\mathrm{E}_{\mathrm{t}}\left\{\mathrm{G}_{\mathrm{I}}\left[\mathrm{I}_{\mathrm{t}+1}, \mathrm{~K}_{\mathrm{t}+1}\right]\right\}+\eta_{\mathrm{t}}, \\
& \eta_{\mathrm{t}}=\mathrm{h}_{\mathrm{t}+1}^{-} \mathrm{E}_{\mathrm{t}}\left\{\mathrm{p}_{\mathrm{t}+1}^{-}-\mathrm{p}_{\mathrm{t}+1}^{+}: \mathrm{v}_{\mathrm{t}+1}^{-}\right\}+\mathrm{h}_{\mathrm{t}+1}^{0} \mathrm{E}_{\mathrm{t}}\left\{\mathrm{q}_{\mathrm{t}+1}-\mathrm{p}^{+}{ }_{\mathrm{t}+1}: \mathrm{v}_{\mathrm{t}+1}^{0}\right\} .
\end{aligned}
$$

Substituting $\mathrm{q}_{\mathrm{t}}$ and $\mathrm{E}_{\mathrm{t}}\left\{\mathrm{q}_{\mathrm{t}+1}\right\}$ in equation (8) with equations (9) and (13), respectively, we obtain the following Euler equation,

$-\left(\mathrm{p}^{+}{ }_{\mathrm{t}}+\mathrm{G}_{\mathrm{I}}\left[\mathrm{I}_{\mathrm{t}}, \mathrm{K}_{\mathrm{t}}\right]\right)\left(1+\mathrm{r}_{\mathrm{t}}+\delta\right)+\left(\pi_{\mathrm{K}, \mathrm{t}}+\mathrm{E}_{\mathrm{t}}\left\{\mathrm{p}^{+}{ }_{\mathrm{t}+1}\right\}+\mathrm{E}_{\mathrm{t}}\left\{\mathrm{G}_{\mathrm{I}}\left[\mathrm{I}_{\mathrm{t}+1}, \mathrm{~K}_{\mathrm{t}+1}\right]\right\}+\eta_{\mathrm{t}}\right)=0$.

\subsection{Frictions and the irreversibility premium}

The intertemporal tradeoff described in equation (15) can be interpreted in terms of a perturbation argument. Along the optimal capital accumulation path, the firm is indifferent to an increase in capital by 1 unit in period $t$ and a decrease of 1 unit in $t+1$, thus leaving the capital stock unaffected from period $t+1$ onward. The cost of this perturbation is represented by $\mathrm{p}_{\mathrm{t}}^{+}+\mathrm{G}_{\mathrm{I}}\left[\mathrm{I}_{\mathrm{t}}, \mathrm{K}_{\mathrm{t}}\right]$ ) - the marginal purchase cost and marginal convex adjustment costs incurred in period t. In the absence of costly reversibility, perturbing the capital stock creates two benefits, $\pi_{\mathrm{K}, \mathrm{t}}$-- the marginal revenue product of capital -- and $\mathrm{E}_{\mathrm{t}}\left\{\mathrm{p}^{+}{ }_{\mathrm{t}+1}+\mathrm{G}_{\mathrm{I}}\left[\mathrm{I}_{\mathrm{t}+1}, \mathrm{~K}_{\mathrm{t}+1}\right]\right\}$-- the expected saving in period $t+1$. This saving arises because the period $t$ investment removes the need to acquire an additional unit of capital in period $\mathrm{t}+1$ to remain on the optimal accumulation path. The Euler equation adjusts for discounting and depreciation $\left(1+\mathrm{r}_{\mathrm{t}}+\delta\right)$, and equates benefits and costs expressed in temporally comparable terms.

Frictions due to costly reversibility and fixed costs impede the firm in equating known costs to expected benefits. These frictions create three regimes in which optimal investment is

positive, negative, or zero. The standard Euler equation is based on the assumption that the firm will be in the positive investment regime in period $\mathrm{t}+1$. However, in the face of irreversibility constraints, the firm must account for the possibility that, even if it is in the positive investment regime in period $t$, it may find itself in the zero or negative investment regimes in period $\mathrm{t}+1$. 
The impacts of these possible deviations from the positive investment regime are captured by $\eta_{\mathrm{t}}$ defined in equation (14). With probability $\mathrm{h}^{-}{ }_{\mathrm{t}+1}$, the firm will realize a shock so that reselling capital is now optimal in $\mathrm{t}+1$ and the period $\mathrm{t}+1$ saving expected in period $\mathrm{t}$ vanishes. Anticipating this possibility, the firm "discounts" the saving it expects to receive in period $\mathrm{t}+1$. This discount is the product of the probability of entering the disinvestment regime $\left(\mathrm{h}^{-}{ }_{\mathrm{t}+1}\right)$ and the cost of being in this regime, the latter measured by the difference between resale and purchase prices $\left(p_{t+1}^{-}-p_{t+1}^{+}\right)$. This argument implies that the first term in $\eta_{t}$ is negative.

The possibility of entering the zero investment regime in period $t+1$ is analyzed in a similar manner. With probability $\mathrm{h}_{\mathrm{t}+1}^{0}$, the firm will find itself in the zone of inaction in period $\mathrm{t}+1$, and the expected saving vanishes. This loss $\left(\mathrm{p}^{+} \mathrm{t+1}\right)$ is partly compensated by the returns from the unwanted unit of capital valued at $\mathrm{q}_{\mathrm{t}+1}$. As with the negative investment regime, the discount is the product of probability $\left(\mathrm{h}_{\mathrm{t}+1}^{0}\right)$ and cost $\left(\mathrm{q}_{\mathrm{t}+1}-\mathrm{p}^{+}{ }_{\mathrm{t}+1}\right)$. If there are no fixed costs, this cost term and hence the second term in $\eta_{t}$ are non-positive. ${ }^{5}$ However, fixed costs create some ambiguity, as $\mathrm{q}_{\mathrm{t}+1}$ now varies both below and above $\mathrm{p}^{+}{ }_{t+1}$, and the sign of the second term in $\eta_{\mathrm{t}}$ depends on the distribution of $\mathrm{q}_{\mathrm{t}+1} .{ }^{6}$ Since the second term may nonetheless be negative even with fixed costs and $\mathrm{h}^{-}{ }_{\mathrm{t}+1}$ is much larger than $\mathrm{h}^{0}{ }_{\mathrm{t}+1}$ in our dataset, the model suggests that $\eta_{\mathrm{t}}$ will be negative.

The derived discount wedge $\eta_{\mathrm{t}}$ reflects the "reluctance to invest" that is a hallmark of the irreversibility literature (Caballero, 1999). In a discrete time model, Bertola and Caballero (1994, Section 2) show that the marginal product of capital under irreversibility exceeds the Jorgensonian user cost applicable when investment is costlessly reversible. In the continuous time model of Abel and Eberly (1996b, Section V; 1999, Section 2), optimal investment occurs only when the marginal revenue product of capital reaches a barrier equal to the Jorgensonian user cost plus a term reflecting irreversibility and uncertainty. Dixit and Pindyck (1994, Chapter

\footnotetext{
${ }^{5}$ Without fixed costs, $\mathrm{q}_{\mathrm{t}+1}$ is never greater than $\mathrm{p}_{\mathrm{t}+1}^{+}$in the zero investment regime because the critical value of $q$ demarcating the zero investment and positive investment regimes is $\mathrm{q}_{\mathrm{t}}^{+}=\mathrm{p}_{\mathrm{t}+1}^{+}$and, by the definition of the zero investment regime, $\mathrm{q}_{\mathrm{t}+1} \leq \mathrm{q}_{\mathrm{t}}^{+}$. See Abel and Eberly (1994, p. 1374, Figure 1) with $\mathrm{c}_{\mathrm{I}}[0, \mathrm{~K}]^{+}=\mathrm{p}_{\mathrm{t}+1}^{+}$and $\mathrm{c}[0, \mathrm{~K}]=\mathrm{F}=0$.

${ }^{6}$ This positive effect of fixed costs on $\eta_{\mathrm{t}}$ and the associated investment stimulus is consistent with optimizing behavior. When in period $t$ the firm expects both to be in the zone of inaction in period $t+1$ and $\mathrm{q}_{\mathrm{t}+1}>\mathrm{p}_{\mathrm{t}+1}^{+}$(i.e., $\mathrm{E}_{\mathrm{t}}\left\{\mathrm{q}_{\mathrm{t}+1}-\mathrm{p}_{\mathrm{t}+1}^{+}: \mathrm{v}_{\mathrm{t}+1}^{0}\right\}>0$ ), it has an incentive to increase investment in period $\mathrm{t}$ so that it has sufficient capital in period $t+1$ to earn rents $\left(q_{t+1}-p_{t+1}^{+}\right)$. We thank Janice Eberly for noting this (initially) counterintuitive result.
} 
5) analyze the option to invest today versus tomorrow and show that the marginal product of capital triggering the investment outlay is higher under irreversibility and uncertainty. A similar result holds in our model with $\eta_{\mathrm{t}}$.

To relate $\eta_{\mathrm{t}}$ to the discount rates emphasized in the literature, we normalize the discount wedge by the marginal value of an additional unit of capital,

$$
\theta_{\mathrm{t}} \equiv-\eta_{\mathrm{t}} / \mathrm{q}_{\mathrm{t}}
$$

and rewrite the intertemporal tradeoff as follows,

$$
-\left(\mathrm{p}_{\mathrm{t}}^{+}+\mathrm{G}_{\mathrm{I}}\left[\mathrm{I}_{\mathrm{t}}, \mathrm{K}_{\mathrm{t}}\right]\right)\left(1+\mathrm{r}_{\mathrm{t}}+\delta+\theta_{\mathrm{t}}\right)+\left(\pi_{\mathrm{K}, \mathrm{t}}+\mathrm{E}_{\mathrm{t}}\left\{\mathrm{p}_{\mathrm{t}+1}^{+}\right\}+\mathrm{E}_{\mathrm{t}}\left\{\mathrm{G}_{\mathrm{I}}\left[\mathrm{I}_{\mathrm{t}+1}, \mathrm{~K}_{\mathrm{t}+1}\right]\right\}\right)=0 .
$$

Thus, costly reversibility and fixed costs under uncertainty raise the effective discount rate guiding investment decisions from $r_{t}$ to $\left(r_{t}+\theta_{t}\right)$. This extra term, $\theta_{t}$, is the "irreversibility premium" estimated in this paper.

\subsection{Non-positive investment in period $t$}

The above derivation and discussion was based on the assumption that the firm was in the positive investment regime in period t. This approach, while standard in the convex adjustment cost literature, must be modified when studying irreversibility in order to allow for zero investment or negative investment in period $t$. When the firm is in the zero or negative investment regimes in period $t$, the relationship in equation (9) between $q_{t}$ and the sum of the purchase price plus marginal convex adjustment costs will not hold. Equation (9) is a special case of equation (5) that holds only for the positive investment regime. We use equation (9) as a benchmark because the purchase price of new capital is available to the econometrician and define $\omega_{\mathrm{t}}$ as the difference between $\mathrm{q}_{\mathrm{t}}$ and the purchase price of new capital plus marginal convex adjustment costs,

$$
\omega_{t} \equiv q_{t}-\left(p_{t}^{+}+G_{I}\left[I_{t}, K_{t}\right]\right)
$$


With equation (18), we can formulate a more general version of the relationship between $\mathrm{q}$ and the marginal cost of adding or removing a unit of capital, a version that will hold in each of the three investment regimes, by rewriting equation (5) as follows,

$$
\mathrm{q}_{\mathrm{t}}=\mathrm{C}_{\mathrm{I}}\left[\mathrm{I}_{\mathrm{t}}, \mathrm{K}_{\mathrm{t}}\right]=\mathrm{p}_{\mathrm{t}}^{+}+\mathrm{G}_{\mathrm{I}}\left[\mathrm{I}_{\mathrm{t}}, \mathrm{K}_{\mathrm{t}}\right]+\omega_{\mathrm{t}}
$$

In the three regimes, $\omega_{\mathrm{t}}$ takes on the following values: positive investment, $\omega_{\mathrm{t}}=0$; negative investment, $\omega_{\mathrm{t}}=\mathrm{p}_{\mathrm{t}}^{-}-\mathrm{p}^{+}$; zero investment, $\omega_{\mathrm{t}}=\mathrm{q}_{\mathrm{t}}-\mathrm{p}^{+}{ }_{\mathrm{t}}$. In the cases of negative or zero investment, $\omega_{\mathrm{t}}$ contains an unobservable variable $\left(\mathrm{p}_{\mathrm{t}}^{-}\right.$or $\mathrm{q}_{\mathrm{t}}$, respectively) and, in estimation, will be treated as part of the error term, as discussed in Section 4.1. (We examine the impact of $\omega_{t}$ on the validity of the estimating equation in Section 8) Repeating the above substitutions with equation (5') in place of equation (5), we obtain the following more general version of the intertemporal tradeoff that supplants equation (17),

$-\left(\mathrm{p}^{+}{ }_{\mathrm{t}}+\mathrm{G}_{\mathrm{I}}\left[\mathrm{I}_{\mathrm{t}}, \mathrm{K}_{\mathrm{t}}\right]+\omega_{\mathrm{t}}\right)\left(1+\mathrm{r}_{\mathrm{t}}+\delta+\theta_{\mathrm{t}}\right)+\left(\pi_{\mathrm{K}, \mathrm{t}}+\mathrm{E}_{\mathrm{t}}\left\{\mathrm{p}_{\mathrm{t}+1}^{+}\right\}+\mathrm{E}_{\mathrm{t}}\left\{\mathrm{G}_{\mathrm{I}}\left[\mathrm{I}_{\mathrm{t}+1}, \mathrm{~K}_{\mathrm{t}+1}\right]\right\}\right)=0$.

Thus, the intertemporal tradeoff that holds for negative or zero investment is similar in form to the intertemporal tradeoff that holds for positive investment.

\section{From theory to estimation}

\subsection{Specification issues}

In order to estimate equation (19), we need to make several additional assumptions.

First, the two variables dated $\mathrm{t}+1$ are evaluated under the assumption of rational expectations: $\mathrm{E}_{\mathrm{t}}\left\{\mathrm{X}_{\mathrm{t}+1}\right\}=\mathrm{X}_{\mathrm{t}+1}+\mathrm{v}_{\mathrm{t}}$, where $\mathrm{X}_{\mathrm{t}}=\left\{\mathrm{p}_{\mathrm{t}+1}^{+}, \mathrm{G}_{\mathrm{I}}\left[\mathrm{I}_{\mathrm{t}+1}, \mathrm{~K}_{\mathrm{t}+1}\right]\right\}$ and $\mathrm{v}_{\mathrm{t}}$ is an expectation error. Second, we assume that the irreversibility premium is constant over time. Third, the technology shock $\left(\varepsilon_{t}\right)$ affecting marginal productivity enters additively. Fourth, the unobservable $\omega_{\mathrm{t}}$ becomes part of the error term.

As noted in the introduction, other influences besides irreversibility may affect the discount rate that firms use in evaluating investment projects. We adjust the market discount rate $\left(r_{t}\right)$ for systematic risk, inflation, and taxes, as discussed in Section 4.2 and the Data Appendix. Moreover, we capture the effects of factors common to all firms by including a 
parameter, $\psi$, in the econometric equation. With these modifications, the irreversibility premium is computed as the difference between the effective discount rates when firms are likely to face binding irreversibility constraints and the remaining observations. Based on these assumptions, equation (19) is written as follows,

$$
\begin{gathered}
-\left(\mathrm{p}_{\mathrm{t}}^{+}+\mathrm{G}_{\mathrm{I}}\left[\mathrm{I}_{\mathrm{t}}, \mathrm{K}_{\mathrm{t}}\right]\right)\left(1+\mathrm{r}_{\mathrm{t}}+\delta_{\mathrm{t}}+\psi+\theta \Gamma_{\mathrm{t}}\right)+\left(\pi_{\mathrm{K}, \mathrm{t}}+\mathrm{p}_{\mathrm{t}+1}^{+}+\mathrm{G}_{\mathrm{I}}\left[\mathrm{I}_{\mathrm{t}+1}, \mathrm{~K}_{\mathrm{t}+1}\right]\right)=\mathrm{u}_{\mathrm{t}}, \\
\mathrm{u}_{\mathrm{t}} \equiv \varpi_{\mathrm{t}}-\mathrm{v}_{\mathrm{t}}-\varepsilon_{\mathrm{t}}
\end{gathered}
$$

where $\Gamma_{\mathrm{t}}$ is an indicator variable (1 if an observation falls into a class with a high probability of facing a binding irreversibility constraint, 0 otherwise $), \varpi_{t}$ equals $\omega_{t}\left(1+r_{t}+\delta_{t}+\psi+\theta \Gamma_{t}\right)$, and $u_{t}$ is a composite error term. We have added a time subscript to $\delta$ because we allow for time-varying depreciation rates, as described in the Data Appendix.

To complete the estimating equation, the marginal adjustment cost and marginal revenue product functions need to be specified. We assume that the marginal adjustment cost function $\mathrm{G}_{\mathrm{I}}\left[\mathrm{I}_{\mathrm{t}}, \mathrm{K}_{\mathrm{t}}\right]$ depends on the investment/capital ratio. We use the following first-order Taylor approximation,

$$
\mathrm{G}_{\mathrm{I}}\left[\mathrm{I}_{\mathrm{t}}, \mathrm{K}_{\mathrm{t}}\right]=\alpha\left(\mathrm{I}_{\mathrm{t}} / \mathrm{K}_{\mathrm{t}}\right)
$$

The marginal revenue product of capital depends on the underlying production and adjustment cost functions and product market characteristics. The production function is assumed to be homogeneous of degree $(1+\xi)$, where $\xi$ is not necessarily equal to zero. Product markets may be imperfectly competitive, and the demand schedule has a constant elasticity of $\mu \geq 0$. Using Euler's Theorem on Homogeneous Functions, we obtain the following specification for the marginal revenue product of capital,

$$
\pi_{\mathrm{K}, \mathrm{t}}=\zeta^{*}\left(\mathrm{SALES}_{\mathrm{t}} / \mathrm{K}_{\mathrm{t}}\right)-\left(\operatorname{COST}_{\mathrm{t}} / \mathrm{K}_{\mathrm{t}}\right)+\mathrm{G}_{\mathrm{I}}\left[\mathrm{I}_{\mathrm{t}}, \mathrm{K}_{\mathrm{t}}\right]^{*}\left(\mathrm{I}_{\mathrm{t}} / \mathrm{K}_{\mathrm{t}}\right)
$$

where $\left(\mathrm{SALES}_{\mathrm{t}} / \mathrm{K}_{\mathrm{t}}\right)$ and $\left(\mathrm{COST}_{\mathrm{t}} / \mathrm{K}_{\mathrm{t}}\right)$ are sales revenues and variable costs, respectively, divided by the beginning-of-period capital stock, $\mathrm{G}_{\mathrm{I}}\left[\mathrm{I}_{\mathrm{t}}, \mathrm{K}_{\mathrm{t}}\right]$ is defined in equation (21), and $\zeta$ equals $\zeta \equiv$ 
$(1+\xi)(1-\mu)$, thus capturing the combined effects of non-constant returns to scale and imperfect competition. Decreasing returns to scale and/or non-competitive product markets imply that $\zeta<1$.

The main econometric results are based on the Euler equation (20a) estimated by GMM with the following instruments: $\left(1-\tau_{t-1}\right)\left(S A L E S_{t-1} / K_{t-1}\right),\left(1-\tau_{t-1}\right)\left(I_{t-1} / K_{t-1}\right)$, $\left(1-\tau_{t-1}\right)\left(1+r_{f, t-1}+\delta_{, t-1}\right),\left(1-i t c_{s, t-1}-z_{s, t-1}\right)\left(p_{s, t-1}^{I} / p_{s, t-1}^{Y}\right)$, and an indicator variable $\left(\Gamma_{\mathrm{t}}\right)$ identifying a class of observations likely to face a binding irreversibility constraint, where $\tau_{\mathrm{t}}$ is the marginal corporate income tax rate, $r_{f, t}$ is the real, risk-adjusted market discount rate for firm $\mathrm{f}, \delta_{s, t}$ is the depreciation rate for sector $\mathrm{s}$, itc $\mathrm{s}_{\mathrm{s}, \mathrm{t}}$ is the investment tax credit rate, $\mathrm{z}_{\mathrm{s}, \mathrm{t}}$, is the present value of depreciation allowances per dollar of investment spending, $p_{s, t}^{I}$ is the price of capital goods, and $p_{s, t}^{Y}$ is the price of output. ${ }^{7}$

\subsection{Panel Dataset}

The panel data consists of 127,863 observations on 16,140 firms for the period 19802001. ${ }^{8}$ The primary data source is CompuStat with additional information obtained from CRSP and various sources of industry and aggregate data. Details about the data are contained in the Data Appendix.

In studying non-convexities, a large panel dataset is essential in order to obtain a meaningful number of observations in the positive, negative, and zero investment regimes. We maximize the size of the dataset used in estimation in three ways. First, we use an unbalanced

\footnotetext{
${ }^{7}$ Andrews and $\mathrm{Lu}$ (2001) discuss the role of the J statistic in detecting correlation between the instruments and unobserved fixed effects in the error term (which, if present, could lead to inconsistent parameter estimates). As shown below in Table 2 (and other tables), the J statistic for the non-convex adjustment cost model provides no evidence of such a correlation (and the model fits better without first differencing to remove fixed effects, perhaps because of the stronger link between instruments and Euler equation variables in levels), so we do not first difference the model. Other studies, using slightly different specifications and data, find that first differencing can be useful in estimating Euler equations.

${ }^{8}$ The number of observations used in estimating the Euler equation is smaller because: 1) some of the required variables (including classification variables) are not available for specific observations; 2) some observations are lost because the required leads and lags are not available; 3 ) we trim the sample, as discussed below, to eliminate unreliable data (although this results in a smaller loss of observations than either 1) or 2)).
} 
panel and thus avoid the severe data restrictions imposed by a balanced panel. This choice has the further advantage of attenuating survivorship bias. Second, even in an unbalanced panel, some methods of constructing the replacement value of the capital stock require long strings of contiguous data to implement the perpetual inventory formula. We partly avoid this problem by tailoring our algorithm to preserve observations when there are gaps in the data and to use data that are more frequently available in CompuStat (e.g., when we find evidence of substantial acquisitions and divestitures, we use data on property, plant, and equipment in addition to the capital expenditure data). An additional problem posed by the perpetual inventory formula is its dependence on an initial or seed value of the capital stock drawn from financial statements. This initial value can be a particularly poor measure of the replacement cost of capital that distorts the computed capital stock until the impact of the initial value is largely depreciated. One solution to this problem is to compute the capital stock for many years before using these data in estimation, but this approach discards a substantial number of observations. As an alternative, we adopt the procedure discussed in detail in Chirinko and Schaller (2004b) that computes an adjustment factor for the initial value taken from the financial statements. Third, the Euler equation and the instruments we have chosen require only three years of contiguous data.

Our efforts to preserve observations make a substantial difference in the number of cases of zero and negative investment in the dataset. For example, firms with less than 10 years of data account for approximately one-half of the zero investment observations. More than twothirds of the zero investment observations are for firms with gaps in their data series.

The market discount rate is constructed in several steps. We begin with a weighted average of the nominal returns to debt and equity, where the weights vary by sector. The nominal return to debt is adjusted for the tax deductibility of interest payments. The nominal return to equity is based on the CAPM and thus accounts for systematic risk. The nominal weighted average is converted to a real return with an inflation adjustment that varies across sectors and over time.

The other variables used in this study are constructed as follows. Gross nominal investment is capital expenditures computed in a two-step procedure. We begin with the data on capital expenditures (CompuStat item 128). CompuStat does not always have reliable data for the changes to the capital stock associated with large acquisitions or divestitures, and we modify the algorithm of Chirinko, Fazzari, and Meyer (1999) to adjust the initial investment data. If the 
financial statement data indicate a substantial acquisition or divestiture, we use accounting identities to derive a more accurate measure of investment that replaces the data from item 128 . Net Sales is CompuStat item 12. Variable costs is the sum of the Cost of Goods Sold (CompuStat item 41) and Selling, General, and Administrative Expense (CompuStat item 189; when this item is not reported, it is set to zero.) The depreciation rate is taken from the BEA, and is allowed to vary across industries and over time. The relative price of investment is the ratio of the price of investment to the price of output. These industry-specific, implicit price deflators are taken from the BEA; the relative price series is adjusted for corporate income taxes.

The firms in our dataset are a representative sample of U.S. publicly traded firms. In fact, the sample approaches the universe of U.S. publicly traded firms. This makes our sample large compared to many previous investment studies. In part, this is because we apply relatively few filters to the data, potentially leading to a more representative sample but also making it possible that some data will be noisy due to mergers, acquisitions, or other corporate events that lead to significant accounting changes. To address this issue, we use 3\% trimming of the upper and lower tails for SALES/K, COST/K, and I/K.

There is enormous variety in size and capital requirements. Table 1 presents summary statistics (before trimming). For the full sample in column 1, the median ratio of investment to the capital stock is 0.078 . The median capital stock is about $\$ 57$ million (1996 dollars). As is typically the case with firm-level data, the mean capital stock is much larger, about $\$ 10$ billion. Demand uncertainty is the unpredictable variation in the ratio of sales to the capital stock; the median of the variance of the sales/capital residual is 0.296 . Median cost uncertainty is 0.250 . Details of the procedure for calculating demand and cost uncertainty are provided in Section 6.1.3 below. The median depreciation rate is about $8 \%$.

The next four column entries are for subsamples based on four characteristics that will be used in the econometric analysis to identify observations when a firm is likely to face irreversibility constraints.

Of particular interest in a study of non-convex costs of adjustment, about $4 \%$ of the observations have negative investment and about $1 \%$ have zero investment. The amount of capital shed by the median firm when its investment is negative is of the same order of magnitude as the amount of capital added by the median firm when its investment is positive 
Table 1

Summary statistics

\begin{tabular}{|c|c|c|c|c|c|c|c|c|c|c|}
\hline \multirow[b]{2}{*}{ Variable } & \multicolumn{10}{|c|}{ Sample Definition } \\
\hline & $\begin{array}{c}\text { Full } \\
\text { Sample }\end{array}$ & $\begin{array}{l}\text { Limited Resale } \\
\text { Markets } \\
\text { (Synchroni- } \\
\text { city) }\end{array}$ & $\begin{array}{c}\text { Low } \\
\text { Depreciation } \\
\text { Rate }\end{array}$ & $\begin{array}{l}\text { High Demand } \\
\text { Uncertainty }\end{array}$ & $\begin{array}{l}\text { High Cost } \\
\text { Uncertainty }\end{array}$ & $\begin{array}{c}\text { Negative } \\
\text { Industry-wide } \\
\text { Shock }\end{array}$ & $\begin{array}{c}\text { Positive } \\
\text { Investment }\end{array}$ & $\begin{array}{c}\text { Negative } \\
\text { Investment }\end{array}$ & $\begin{array}{c}\text { Zero } \\
\text { Investment }\end{array}$ & $\begin{array}{c}\text { Non-positive } \\
\text { Investment }\end{array}$ \\
\hline $\mathrm{I} / \mathrm{K}$ & $\begin{array}{c}0.078 \\
{[0.269]} \\
(3.795)\end{array}$ & $\begin{array}{c}0.054 \\
{[0.124]} \\
(0.226)\end{array}$ & $\begin{array}{c}0.050 \\
{[0.230]} \\
(3.991)\end{array}$ & $\begin{array}{c}0.115 \\
{[0.223]} \\
(0.866)\end{array}$ & $\begin{array}{c}0.113 \\
{[0.222]} \\
(0.868)\end{array}$ & $\begin{array}{c}0.068 \\
{[0.136]} \\
(0.456)\end{array}$ & $\begin{array}{c}0.085 \\
{[0.288]} \\
(3.887)\end{array}$ & $\begin{array}{c}-0.094 \\
{[-0.145]} \\
(0.225)\end{array}$ & $\begin{array}{c}0.000 \\
{[0.000]} \\
(0.000)\end{array}$ & $\begin{array}{c}-0.059 \\
{[-0.111]} \\
(0.206)\end{array}$ \\
\hline $\mathrm{K}$ & $\begin{array}{c}52.28 \\
{[9259.07]} \\
(69853.35)\end{array}$ & $\begin{array}{c}193.28 \\
{[23858.60]} \\
(112919.81)\end{array}$ & $\begin{array}{c}188.71 \\
{[21128.77]} \\
(106479.34)\end{array}$ & $\begin{array}{c}20.43 \\
{[244.67]} \\
(1644.42)\end{array}$ & $\begin{array}{c}20.39 \\
{[259.70]} \\
(1745.33)\end{array}$ & $\begin{array}{c}50.70 \\
{[1134.26]} \\
(6276.34)\end{array}$ & $\begin{array}{c}56.04 \\
{[9692.39]} \\
(71526.42)\end{array}$ & $\begin{array}{c}20.09 \\
{[607.43]} \\
(3622.63)\end{array}$ & $\begin{array}{c}1.92 \\
{[89.86]} \\
(1261.22)\end{array}$ & $\begin{array}{c}12.45 \\
{[487.31]} \\
(3239.41)\end{array}$ \\
\hline $\begin{array}{c}\text { Demand } \\
\text { Uncertainty }\end{array}$ & $\begin{array}{c}0.314 \\
{[18.661]} \\
(353.423)\end{array}$ & $\begin{array}{c}0.233 \\
{[12.341]} \\
(366.773)\end{array}$ & $\begin{array}{c}0.153 \\
{[8.109]} \\
(216.878)\end{array}$ & $\begin{array}{c}1.308 \\
{[27.482]} \\
(361.408)\end{array}$ & $\begin{array}{c}1.309 \\
{[27.575]} \\
(362.111)\end{array}$ & $\begin{array}{c}0.296 \\
{[14.091]} \\
(286.550)\end{array}$ & $\begin{array}{c}0.306 \\
{[17.290]} \\
(332.149)\end{array}$ & $\begin{array}{c}0.588 \\
{[40.872]} \\
(559.937)\end{array}$ & $\begin{array}{c}0.467 \\
{[82.627]} \\
(1025.088)\end{array}$ & $\begin{array}{c}0.580 \\
{[47.536]} \\
(656.672)\end{array}$ \\
\hline $\begin{array}{c}\text { Cost } \\
\text { Uncertainty }\end{array}$ & $\begin{array}{c}0.262 \\
{[16.312]} \\
(306.051)\end{array}$ & $\begin{array}{c}0.190 \\
{[10.876]} \\
(330.375)\end{array}$ & $\begin{array}{c}0.136 \\
{[6.270]} \\
(116.425)\end{array}$ & $\begin{array}{c}1.024 \\
{[23.921]} \\
(307.368)\end{array}$ & $\begin{array}{c}1.045 \\
{[24.034]} \\
(307.965)\end{array}$ & $\begin{array}{c}0.259 \\
{[11.545]} \\
(218.913)\end{array}$ & $\begin{array}{c}0.256 \\
{[15.025]} \\
(284.212)\end{array}$ & $\begin{array}{c}0.497 \\
{[37.003]} \\
(507.092)\end{array}$ & $\begin{array}{c}0.468 \\
{[77.153]} \\
(963.820)\end{array}$ & $\begin{array}{c}0.494 \\
{[43.411]} \\
(603.648)\end{array}$ \\
\hline $\begin{array}{c}\text { Depreciation } \\
\text { Rate }\end{array}$ & $\begin{array}{c}0.079 \\
{[0.089]} \\
(0.033)\end{array}$ & $\begin{array}{c}0.076 \\
{[0.077]} \\
(0.024)\end{array}$ & $\begin{array}{c}0.068 \\
{[0.066]} \\
(0.013)\end{array}$ & $\begin{array}{c}0.089 \\
{[0.098]} \\
(0.033)\end{array}$ & $\begin{array}{c}0.089 \\
{[0.098]} \\
(0.033)\end{array}$ & $\begin{array}{c}0.081 \\
{[0.095]} \\
(0.037)\end{array}$ & $\begin{array}{c}0.079 \\
{[0.088]} \\
(0.033)\end{array}$ & $\begin{array}{c}0.084 \\
{[0.094]} \\
(0.035)\end{array}$ & $\begin{array}{c}0.080 \\
{[0.090]} \\
(0.032)\end{array}$ & $\begin{array}{c}0.083 \\
{[0.093]} \\
(0.034)\end{array}$ \\
\hline Firms & 16140 & 5646 & 6498 & 4577 & 4577 & 4523 & 16030 & 3470 & 719 & 3928 \\
\hline Observations & 127863 & 47447 & 53784 & 36678 & 36535 & 11494 & 121844 & 4622 & 1397 & 6019 \\
\hline
\end{tabular}

Median, [mean], (standard deviation). $\mathrm{K}$ is the capital stock, $\mathrm{I} / \mathrm{K}$ is the investment/capital ratio, Demand Uncertainty is the variance of shocks to sales from a vector autoregression with the main variables relevant for investment -- sales, costs, the discount factor, the relative price of investment goods, and the investment/capital ratio, and Cost Uncertainty is the variance of shocks to costs from the same vector autoregression. (Sales and costs are both normalized by the capital stock.) See Section 4 for precise definitions of the classes of firms and the Data Appendix for data sources and variable construction. 
(in both cases, measuring investment relative to the firm's capital stock). Observations with negative investment tend to come from smaller firms and firms that face more demand and cost uncertainty. The median depreciation rates are similar for observations with positive and negative investment

\section{Tests of Competing Models}

In Section 3, we derive the empirical specification for the non-convex adjustment cost model. It is straightforward to derive the corresponding empirical specification for the convex adjustment cost model as a special case. In this section, we derive this special case and then test the competing models.

The two features that lead to non-convexities are: 1) the difference between the purchase and resale price of capital; and 2) the presence of fixed costs. If $\mathrm{p}^{+}=\mathrm{p}^{-}$and $\mathrm{F}=0$, then

$\mathrm{C}[\mathrm{I}, \mathrm{K}]=\mathrm{p}^{+} \mathrm{I}+\mathrm{G}[\mathrm{I}, \mathrm{K}]$

$\mathrm{q}_{\mathrm{t}}=\mathrm{C}_{\mathrm{I}}\left[\mathrm{I}_{\mathrm{t}}, \mathrm{K}_{\mathrm{t}}\right]=\mathrm{p}_{\mathrm{t}}^{+}+\mathrm{G}_{\mathrm{I}}\left[\mathrm{I}_{\mathrm{t}}, \mathrm{K}_{\mathrm{t}}\right]$.

Equations (7) and (8) are unchanged. Equation (11) simplifies to

$\mathrm{E}_{\mathrm{t}}\left\{\mathrm{q}_{\mathrm{t}+1}\right\}=\mathrm{E}_{\mathrm{t}}\left\{\mathrm{p}_{\mathrm{t}+1}^{+}+\mathrm{G}_{\mathrm{I}}\left[\mathrm{I}_{\mathrm{t}+1}, \mathrm{~K}_{\mathrm{t}+1}\right]\right.$.

Equation (11') implies that $\eta_{\mathrm{t}}=0$ in (13) and (15). Since there is no difference between purchase and resale prices for capital, $\mathrm{p}_{t+\mathrm{j}}^{+}=\mathrm{p}_{\mathrm{t}+\mathrm{j}}$ for $\mathrm{j}=0,1, \ldots$. Thus $\theta_{\mathrm{t}}=0$. The resulting Euler equation for the convex adjustment cost model is

$$
\begin{gathered}
-\left(\mathrm{p}_{\mathrm{t}}+\mathrm{G}_{\mathrm{I}}\left[\mathrm{I}_{\mathrm{t}}, \mathrm{K}_{\mathrm{t}}\right]\right)\left(1+\mathrm{r}_{\mathrm{t}}+\delta_{\mathrm{t}}+\psi\right)+\left(\pi_{\mathrm{K}, \mathrm{t}}+\mathrm{p}_{\mathrm{t}+1}+\mathrm{G}_{\mathrm{I}}\left[\mathrm{I}_{\mathrm{t}+1}, \mathrm{~K}_{\mathrm{t}+1}\right]\right)=\mathrm{u}_{\mathrm{t}}, \\
\mathrm{u}_{\mathrm{t}} \equiv-\mathrm{v}_{\mathrm{t}}-\varepsilon_{\mathrm{t}}
\end{gathered}
$$

If we estimate the convex adjustment cost model, but non-convex adjustment costs are present in the data, the Euler equation error term will be 


$$
\mathrm{u}_{\mathrm{t}}=\varpi_{\mathrm{t}}-\mathrm{v}_{\mathrm{t}}-\varepsilon_{\mathrm{t}}+\left(\mathrm{p}_{\mathrm{t}}^{+}+\mathrm{G}_{\mathrm{I}}\left[\mathrm{I}_{\mathrm{t}}, \mathrm{K}_{\mathrm{t}}\right]\right) \theta \Gamma_{\mathrm{t}}
$$

Thus, if non-convex adjustment costs are present in the data and we ignore them, an additional term that is not present in equation (20b) will appear in the error for the investment Euler equation, $\left(\mathrm{p}_{\mathrm{t}}^{+}+\mathrm{G}_{\mathrm{I}}\left[\mathrm{I}_{\mathrm{t}}, \mathrm{K}_{\mathrm{t}}\right]\right) \theta \Gamma_{\mathrm{t}}$. Since this term includes many elements (the price of capital goods, marginal adjustment costs, the irreversibility premium, and the indicator variable for a class of firms with a high probability of facing a binding irreversibility constraint) that are not present in the Euler equation error in $(20 b)$ or $\left(20 b^{\prime}\right)$, a standard test of overidentifying restrictions may have power to distinguish between the convex and non-convex adjustment cost models.

The first row of Table 2 reports the test of overidentifying restrictions for the convex adjustment cost model (estimated on the full sample). The $\mathrm{J}$ statistic is 28.854 , so the convex adjustment cost model is rejected with a p-value of $0.000 .^{9}$

A natural question is whether the rejection of the convex adjustment cost model is due to the presence of non-convex adjustment costs or some other specification issue. To test this, we first estimate the convex adjustment cost model on a subsample of firms that are particularly unlikely to face binding irreversibility constraints -- firms in industries with thick resale markets, which have high depreciation rates, and which face low demand uncertainty. ${ }^{10}$ For this subsample of firms, the $\mathrm{J}$ statistic is 1.616 (with a p-value of 0.204 , as shown in the second row of Table 2), so the convex adjustment cost model fits the data for firms that are unlikely to face binding irreversibility constraints.

\footnotetext{
${ }^{9}$ We used a smaller set of instruments $\left(\left(1-\tau_{t-1}\right)\left(S A L E S_{t-1} / K_{t-1}\right),\left(1-\tau_{t-1}\right)\left(I_{t-1} / K_{t-1}\right)\right.$, $\left.\left(1-\tau_{t-1}\right)\left(1+r_{f, t-1}+\delta_{, t-1}\right)\right)$ to estimate the convex adjustment cost model so that the $\mathrm{J}$ statistic will have the same degrees of freedom for both the convex and non-convex adjustment cost models. The results in the first two rows of Table 2 are the same if we include either or both of the two additional instruments that we use to estimate the non-convex adjustment cost model and adjust the degrees of freedom for the $\mathrm{J}$ statistic; i.e., the convex adjustment cost model is strongly rejected for the full sample, but the data fail to reject it for observations that are unlikely to face binding irreversibility constraints.

${ }^{10}$ We discuss characteristics that affect the likelihood of facing a binding irreversibility constraint in more detail in the next section.
} 
Table 2

\section{Tests of Competing Models}

\begin{tabular}{|c|c|c|c|}
\hline Model & Sample & $\mathrm{N}$ & $\mathrm{J}$ \\
\hline $\begin{array}{c}\text { Convex Adjustment } \\
\text { Cost }\end{array}$ & Full & 60,287 & 28.854 \\
{$\left[\begin{array}{c}\text { Convex Adjustment } \\
\text { Cost }\end{array}\right.$} & $\begin{array}{c}\text { Unlikely to face } \\
\text { binding } \\
\text { irreversibility } \\
\text { constraints }\end{array}$ & 2,549 & 1.616 \\
& Full & & {$[0.204]$} \\
\hline $\begin{array}{c}\text { Non-Convex } \\
\text { Adjustment Cost }\end{array}$ & & 60,287 & 0.024 \\
\hline
\end{tabular}

The $\mathrm{J}$ statistic is the Hansen $\mathrm{J}$ statistic for testing overidentifying restrictions (with $\mathrm{p}$-value in brackets). $\mathrm{N}$ is the number of observations. Observations for which irreversibility constraints are unlikely to bind are defined as those with thick resale markets, high depreciation rates, and low demand uncertainty. In the non-convex adjustment cost model, $\Gamma_{\mathrm{t}}$ is set equal to 1 for observations with low depreciation rates, where $\Gamma_{\mathrm{t}}$ is an indicator variable identifying a class of observations likely to face a binding irreversibility constraint. (Table 3 provides additional results for other choices of $\Gamma_{t}$.)

Although the details differ, the results in the first two rows of Table 2 are consistent with evidence in Whited (1998), who finds that the overidentifying restrictions of the convex adjustment cost model are less strongly rejected for observations that are less likely to face binding irreversibility constraints.

As a further test between the competing models, we estimate the non-convex adjustment cost model. The third row of Table 2 reports that the $\mathrm{J}$ statistic for the non-convex adjustment cost model is 0.024 (with a p-value of 0.876 ) when estimated on the full sample.

The three tests reported in Table 2 provide evidence that the model with non-convex adjustment costs is more consistent with the data than the model with only convex adjustment costs. In the next section, we estimate the economic importance of non-convex adjustment costs. 


\section{Estimates of the Irreversibility Premium}

\subsection{Characteristics that affect the irreversibility premium}

\subsubsection{Limited resale markets}

In order for the problem of irreversibility to arise, firms must face some difficulty in reselling previously acquired capital goods. In some theoretical work, this constraint is modeled as a complete inability to sell capital goods (e.g., Bertola and Caballero, 1994; Dixit and Pindyck, 1994). More generally, irreversibility can be modeled as a gap between the purchase and resale prices of capital goods, as we have done in Section 2. ${ }^{11}$ We introduce two innovative approaches to measuring limited resale markets.

First, we collect data on new and used capital goods transactions by industry from the Annual Capital Expenditures survey of the U.S. Census Bureau and define the variable "used" as the ratio of the sum of expenditures on used capital equipment to the sum of total (new plus used) capital expenditures. We define an industry as having limited resale markets by the thin markets criterion if "used" is below the median over all industries. The first column of Table 3 presents estimates of the irreversibility premium based on the thin markets definition of limited resale markets. The estimated irreversibility premium is 110 basis points (with a standard error of 100 basis points).

The second approach is based on Shleifer and Vishny (1992), who develop a model of the liquidation value of assets. In their model, the best buyers of assets (from the perspective of the seller) are other firms in the same industry, since they compete to purchase the asset at a price at or near the "value in best use." Liquidation values will therefore tend to be reduced if the shocks that hit firms in the industry are highly synchronised. We empirically estimate synchronicity using the average correlation between stock market returns for all firms in the industry. ${ }^{12}$ An industry is classified as having high synchronicity if it is above the median

\footnotetext{
${ }^{11}$ Data on purchase and resale prices are seldom available. Two notable exceptions are the studies by Ramey and Shapiro (2001, U.S. aerospace industry) and Asplund (2000, Swedish metalworking machinery).

${ }^{12}$ For example, suppose an industry has three firms A, B, and C. Then the synchronicity for this industry is simply $(\operatorname{Corr}(\mathrm{A}, \mathrm{B})+\operatorname{Corr}(\mathrm{A}, \mathrm{C})+\operatorname{Corr}(\mathrm{B}, \mathrm{C})) / 3$ where $\operatorname{Corr}(\mathrm{X}, \mathrm{Y})$ denotes the correlation between the returns of $\mathrm{X}$ and the returns of $\mathrm{Y}$.
} 
Table 3

Estimates of the irreversibility premium

\begin{tabular}{|c|c|c|c|c|c|c|}
\hline & \multicolumn{2}{|c|}{$\begin{array}{l}\text { Limited Resale } \\
\text { Markets }\end{array}$} & \multirow{2}{*}{$\begin{array}{c}\text { Low } \\
\text { Depreciation } \\
\text { Rate }\end{array}$} & \multirow[t]{2}{*}{$\begin{array}{l}\text { High Demand } \\
\text { Uncertainty }\end{array}$} & \multirow[t]{2}{*}{$\begin{array}{l}\text { High Cost } \\
\text { Uncertainty }\end{array}$} & \multirow[t]{2}{*}{$\begin{array}{l}\text { Negative Industry- } \\
\text { wide Shock }\end{array}$} \\
\hline & $\begin{array}{c}\text { Thin } \\
\text { Markets }\end{array}$ & $\begin{array}{l}\text { Synchroni- } \\
\text { city }\end{array}$ & & & & \\
\hline$\theta$ & $\begin{array}{c}0.011 \\
(0.010)\end{array}$ & $\begin{array}{c}0.051 \\
(0.008)\end{array}$ & $\begin{array}{c}0.022 \\
(0.008)\end{array}$ & $\begin{array}{c}0.073 \\
(0.007)\end{array}$ & $\begin{array}{c}0.066 \\
(0.008)\end{array}$ & $\begin{array}{c}0.055 \\
(0.025)\end{array}$ \\
\hline$\zeta$ & $\begin{array}{r}0.887 \\
(0.024) \\
\end{array}$ & $\begin{array}{c}0.846 \\
(0.035) \\
\end{array}$ & $\begin{array}{c}0.867 \\
(0.030) \\
\end{array}$ & $\begin{array}{c}0.940 \\
(0.009) \\
\end{array}$ & $\begin{array}{c}0.936 \\
(0.009) \\
\end{array}$ & $\begin{array}{c}0.906 \\
(0.018) \\
\end{array}$ \\
\hline$\alpha$ & $\begin{array}{c}61.895 \\
(17.647 \\
) \\
\end{array}$ & $\begin{array}{c}69.391 \\
(21.653)\end{array}$ & $\begin{array}{c}72.157 \\
(21.307)\end{array}$ & $\begin{array}{l}22.981 \\
(2.958)\end{array}$ & $\begin{array}{l}24.447 \\
(3.176)\end{array}$ & $\begin{array}{c}41.775 \\
(10.099)\end{array}$ \\
\hline $\mathrm{J}$ & $\begin{array}{c}0.000 \\
{[0.998]} \\
\end{array}$ & $\begin{array}{c}0.550 \\
{[0.458]} \\
\end{array}$ & $\begin{array}{c}0.024 \\
{[0.876]} \\
\end{array}$ & $\begin{array}{c}0.616 \\
{[0.433]} \\
\end{array}$ & $\begin{array}{c}0.444 \\
{[0.505]} \\
\end{array}$ & $\begin{array}{c}0.186 \\
{[0.666]} \\
\end{array}$ \\
\hline $\mathrm{N}$ & 59196 & 59908 & 60287 & 45844 & 45844 & 40840 \\
\hline
\end{tabular}

The parameter $\theta$ is the irreversibility premium. The parameter $\zeta$ captures the combined effects of non-constant returns to scale and imperfect competition. The parameter $\alpha$ governs the adjustment cost technology. Standard errors are in parentheses under the parameter estimates. The $\mathrm{J}$ statistic is the Hansen $\mathrm{J}$ statistic for testing overidentifying restrictions (with $\mathrm{p}$-values in brackets). The statistic $\mathrm{N}$ is the number of firm/year observations. Parameter estimates are based on equation (20) with the definitions in equations (21) and (22). The estimation method is GMM with the following instruments: SALES/K, I/K, $1+r+\delta, p^{I} / p^{Y}$ (all for the previous period and adjusted for taxes), and an indicator variable $\left(\Gamma_{\mathrm{t}}\right)$ identifying a class of observations likely to face a binding irreversibility constraint (listed at the top of the column). Section 4.2 and the Data Appendix contain definitions, sources, and details about the construction of the variables, and Section 6 contains precise definitions of the classes.

industry by synchronicity. The second column of the table presents estimates of the irreversibility premium based on the synchronicity definition of limited resale markets. The estimated irreversibility premium is 510 basis points (with a standard error of 80 basis points). ${ }^{13}$

\footnotetext{
${ }^{13}$ Since the synchronicity definition seems to better capture limited resale markets, we focus on this definition in subsequent tables.
} 


\subsubsection{Low depreciation rates}

Suppose a firm finds itself with excess capital but the costs of selling capital (resale discount and fixed costs of negative investment) are too great to induce it to actively shed capital. The only way of reducing its capital stock is through depreciation. In industries with low depreciation rates, this recourse is sharply limited, suggesting that the irreversibility premium can be estimated by focusing on industries with low depreciation rates. In the third column of Table 3, we present estimates of the irreversibility premium for firms in industries with depreciation rates below the median depreciation rate over all industries. The estimated irreversibility premium is 220 basis points (with a standard error of 80 basis points).

\subsubsection{Uncertainty}

In the absence of uncertainty, irreversibility would make no difference to investment behavior. Previous theoretical work suggests that the irreversibility premium is increasing in the degree of uncertainty. In this theoretical work, uncertainty is the variance of demand and/or cost shocks. To construct a corresponding empirical measure of demand uncertainty, we estimate a vector autoregression with the main variables relevant for investment -- sales, costs, the discount factor, the relative price of investment goods, and the investment/capital ratio. Sales and costs are both normalized by the capital stock. (The investment/capital ratio is included because it is a useful forecasting variable under standard assumptions. In models based on convex adjustment costs, I/K reflects the expected present value of future marginal products of capital; more generally, in models with non-convexities, investment will depend on the present value of future marginal products of capital over some range.) Our measure of demand uncertainty is the firmspecific variance of the sales residuals. Firms with variances above the median over all firms are defined as having high demand uncertainty. The fourth column of Table 3 shows that the estimated irreversibility premium is 730 basis points (with a standard error of 70 basis points). The definition of cost uncertainty is directly parallel to the definition of demand uncertainty. The fifth column of the table shows that the estimated irreversibility premium for firms with high cost uncertainty is 660 basis points (with a standard error of 80 basis points). 


\subsubsection{Negative industry-wide shocks}

In standard models of non-convexities, unfavorable shocks tend to push firms toward the irreversibility constraint (or, more generally, toward non-positive investment). The irreversibility constraint is more likely to bind in response to industry-wide negative shocks than firm-specific shocks, since industry-wide shocks will increase both the probability of a firm being forced to undertake zero or negative investment and the cost of operating in either of these two regimes. Think, for example, of the hundreds of commercial airplanes parked in the desert in the southwestern U.S. as a result of the negative shock to the airline industry in the wake of September 11. We define an industry as subject to negative industry-wide shocks if the industry mean of sales residuals from the VAR (described above) over the previous two years is in the lowest $25 \%$ of industry means. As shown in the sixth column of Table 3 , the irreversibility premium is 550 basis points (with a standard error of 250 basis points) for firms subject to industry-wide negative shocks.

\subsection{Combinations of two characteristics that affect the irreversibility premium}

\subsubsection{Limited resale markets}

Just because a firm faces limited resale markets does not mean it is very likely to encounter a binding irreversibility constraint. If the firm has a high depreciation rate, it faces relatively little uncertainty, and its industry is doing well, the probability that the irreversibility constraint will bind is low. If one of these conditions is not met, there is a greater chance that the firm will be stuck with excess capital.

In Table 4a, we examine the interaction between limited resale markets (as measured by high synchronicity) and other variables that might affect the irreversibility premium. The first column shows that the interaction of limited resale markets and low depreciation increases the irreversibility premium by 280 basis points, relative to low depreciation alone. ${ }^{14}$ The second column shows that the combination of high demand uncertainty and limited resale markets increases the irreversibility premium by 350 basis points, relative to high demand uncertainty

\footnotetext{
${ }^{14}$ To see this, subtract the irreversibility premium based on low depreciation alone (220 basis points, from the third column of Table 3 ) from the irreversibility premium based on the interaction of limited resale markets and low depreciation (500 basis points, from the first column of Table $4 a$ ).
} 
alone. The third column shows that the interaction of cost uncertainty and limited resale markets increases the irreversibility premium by 370 basis points. As reported in the fourth column, the combination of negative industry-wide shocks and limited resale markets increases the irreversibility premium by 140 basis points.

Table 4a

Estimates of the Irreversibility Premium

\begin{tabular}{|l|c|c|c|c|}
\hline & \multicolumn{4}{|c|}{ Limited Resale Markets and } \\
\hline & $\begin{array}{c}\text { Low } \\
\text { Depreciation }\end{array}$ & $\begin{array}{c}\text { High } \\
\text { Demand } \\
\text { Uncertainty }\end{array}$ & $\begin{array}{c}\text { High Cost } \\
\text { Uncertainty }\end{array}$ & $\begin{array}{c}\text { Negative } \\
\text { Industry- } \\
\text { wide Shock }\end{array}$ \\
\hline$\theta$ & 0.050 & 0.108 & 0.103 & 0.069 \\
& $(0.012)$ & $(0.011)$ & $(0.011)$ & $(0.036)$ \\
\hline$\zeta$ & 0.842 & 0.896 & 0.896 & 0.903 \\
& $(0.041)$ & $(0.015)$ & $(0.015)$ & $(0.018)$ \\
\hline$\alpha$ & 80.273 & 32.654 & 33.258 & 40.795 \\
& $(26.770)$ & $(6.360)$ & $(6.492)$ & $(10.083)$ \\
\hline $\mathrm{J}$ & 0.007 & 0.323 & 0.307 & 0.522 \\
& {$[0.935]$} & {$[0.570]$} & {$[0.579]$} & {$[0.470]$} \\
\hline $\mathrm{N}$ & 59,908 & 45,567 & 45,567 & 40,587 \\
\hline
\end{tabular}

The parameter $\theta$ is the irreversibility premium. The parameter $\zeta$ captures the combined effects of non-constant returns to scale and imperfect competition. The parameter $\alpha$ governs the adjustment cost technology. Standard errors are in parentheses under the parameter estimates. The $\mathrm{J}$ statistic is the Hansen $\mathrm{J}$ statistic for testing overidentifying restrictions (with $\mathrm{p}$-values in brackets). The statistic $\mathrm{N}$ is the number of firm/year observations. Parameter estimates are based on equation (20) with the definitions in equations (21) and (22). The estimation method is GMM with the following instruments: SALES/K, I/K, $1+r+\delta, p^{I} / p^{Y}$ (all for the previous period and adjusted for taxes), and an indicator variable $\left(\Gamma_{\mathrm{t}}\right)$ identifying a class of observations likely to face a binding irreversibility constraint (listed at the top of the column). Section 4.2 and the Data Appendix contain definitions, sources, and details about the construction of the variables, and Section 6 contains precise definitions of the classes.

\subsubsection{Low depreciation rates}

Table $4 \mathrm{~b}$ uses combinations of a low depreciation rate and other variables to estimate the irreversibility premium. The first column of Table $4 \mathrm{~b}$ presents estimates of the irreversibility premium for firms with low depreciation rates and a high degree of demand uncertainty. The estimated irreversibility premium is 230 basis points higher, relative to high demand uncertainty 
alone. The irreversibility premium is 960 basis points (with a standard error of 120 basis points). Results are similar for cost uncertainty, as shown in the second column. The most striking result in Table 4 is the irreversibility premium for firms that have low depreciation rates and that have suffered recent negative industry-wide shocks. For these firms, the estimated irreversibility

Table 4b

Estimates of the Irreversibility Premium

\begin{tabular}{|l|c|c|c|}
\hline & \multicolumn{3}{|c|}{ Low Depreciation Rates and } \\
\hline & $\begin{array}{c}\text { High } \\
\text { Demand } \\
\text { Uncertainty }\end{array}$ & $\begin{array}{c}\text { High Cost } \\
\text { Uncertainty }\end{array}$ & $\begin{array}{c}\text { Negative } \\
\text { Industry- } \\
\text { wide Shock }\end{array}$ \\
\hline$\theta$ & 0.096 & 0.092 & 0.126 \\
$(0.012)$ & $(0.012)$ & $(0.038)$ \\
\hline$\zeta$ & 0.905 & 0.903 & 0.896 \\
$(0.015)$ & $(0.015)$ & $(0.021)$ \\
\hline$\alpha$ & 35.073 & 35.558 & 45.685 \\
& $(6.909)$ & $(7.050)$ & $(12.165)$ \\
\hline $\mathrm{J}$ & 0.671 & 0.569 & 0.221 \\
& {$[0.413]$} & {$[0.451]$} & {$[0.638]$} \\
\hline $\mathrm{N}$ & 45,844 & 45,844 & 40,840 \\
\hline
\end{tabular}

The parameter $\theta$ is the irreversibility premium. The parameter $\zeta$ captures the combined effects of non-constant returns to scale and imperfect competition. The parameter $\alpha$ governs the adjustment cost technology. Standard errors are in parentheses under the parameter estimates. The $\mathrm{J}$ statistic is the Hansen $\mathrm{J}$ statistic for testing overidentifying restrictions (with $\mathrm{p}$-values in brackets). The statistic $\mathrm{N}$ is the number of firm/year observations. Parameter estimates are based on equation (20) with the definitions in equations (21) and (22). The estimation method is GMM with the following instruments: SALES/K, I/K, $1+r+\delta, p^{I} / p^{Y}$ (all for the previous period and adjusted for taxes), and an indicator variable $\left(\Gamma_{\mathrm{t}}\right)$ identifying a class of observations likely to face a binding irreversibility constraint (listed at the top of the column). Section 4.2 and the Data Appendix contain definitions, sources, and details about the construction of the variables, and Section 6 contains precise definitions of the classes.

premium is 1260 basis points (with a standard error of 380 basis points). The estimates in this column reflect the situation of firms that are particularly likely to want to shed capital - and are unable to do so through depreciation of their existing capital stock. 


\subsubsection{Uncertainty}

Table $4 \mathrm{c}$ uses the combination of a high degree of uncertainty and negative industry-wide shocks to estimate the irreversibility premium. In the wake of negative industry-wide shocks, firms with a high degree of demand uncertainty have an irreversibility premium 350 basis points higher than they do in the absence of these shocks. A similar result (not reported) holds for firms with a high degree of cost uncertainty.

Table 4c

Estimates of the Irreversibility Premium

\begin{tabular}{|l|c|c|}
\hline & \multicolumn{2}{|c|}{ Negative Industry-wide Shock and } \\
\hline & High Demand Uncertainty & $\begin{array}{c}\text { High Cost } \\
\text { Uncertainty }\end{array}$ \\
\hline$\theta$ & 0.108 & 0.093 \\
& $(0.031)$ & $(0.031)$ \\
\hline$\zeta$ & 0.917 & 0.915 \\
& $(0.015)$ & $(0.015)$ \\
\hline$\alpha$ & 37.230 & 37.465 \\
& $(8.317)$ & $(8.432)$ \\
\hline $\mathrm{J}$ & 0.094 & 0.134 \\
& {$[0.759]$} & {$[0.714]$} \\
\hline $\mathrm{N}$ & 40840 & 40840 \\
\hline
\end{tabular}

The parameter $\theta$ is the irreversibility premium. The parameter $\zeta$ captures the combined effects of non-constant returns to scale and imperfect competition. The parameter $\alpha$ governs the adjustment cost technology. Standard errors are in parentheses under the parameter estimates. The $\mathbf{J}$ statistic is the Hansen $\mathbf{J}$ statistic for testing overidentifying restrictions (with $\mathrm{p}$-values in brackets). The statistic $\mathrm{N}$ is the number of firm/year observations. Parameter estimates are based on equation (20) with the definitions in equations (21) and (22). The estimation method is GMM with the following instruments: SALES/K, I/K, $1+r+\delta, p^{I} / p^{Y}$ (all for the previous period and adjusted for taxes), and an indicator variable $\left(\Gamma_{\mathrm{t}}\right)$ identifying a class of observations likely to face a binding irreversibility constraint (listed at the top of the column). Section 4.2 and the Data Appendix contain definitions, sources, and details about the construction of the variables, and Section 6 contains precise definitions of the classes. 


\subsection{Multiple combinations of variables that affect the irreversibility premium}

The firms that are the most likely to face a binding irreversibility constraint are those with limited resale markets, low depreciation, high uncertainty, and negative industry-wide shocks. In Table 5, we examine multiple combinations of these characteristics. Two broad conclusions emerge.

Table 5

Estimates of the Irreversibility Premium Combinations of three or more characteristics

\begin{tabular}{|l|c|c|c|c|c|}
\hline & $\begin{array}{c}\text { Limited Resale } \\
\text { Markets, Low } \\
\text { Depreciation } \\
\text { Rate, High } \\
\text { Demand } \\
\text { Uncertainty }\end{array}$ & $\begin{array}{c}\text { Limited Resale } \\
\text { Markets, Low } \\
\text { Depreciation } \\
\text { Rate, Negative } \\
\text { Industry-wide } \\
\text { Shock }\end{array}$ & $\begin{array}{c}\text { Low } \\
\text { Depreciation } \\
\text { Rate, High } \\
\text { Demand } \\
\text { Uncertainty, } \\
\text { Negative } \\
\text { Industry-wide } \\
\text { Shock }\end{array}$ & $\begin{array}{c}\text { Limited Resale } \\
\text { Markets, High } \\
\text { Demand } \\
\text { Uncertainty, } \\
\text { Negative } \\
\text { Industry-wide } \\
\text { Shock }\end{array}$ & $\begin{array}{c}\text { Limited Resale } \\
\text { Markets, Low } \\
\text { Depreciation Rate, } \\
\text { High Demand } \\
\text { Uncertainty, } \\
\text { Negative Industry- } \\
\text { wide Shock }\end{array}$ \\
\hline$\theta$ & 0.136 & 0.174 & 0.250 & 0.148 & 0.331 \\
\hline$\zeta$ & $(0.021)$ & $(0.048)$ & $(0.061)$ & $(0.053)$ & $(0.077)$ \\
\hline$\alpha$ & 0.878 & 0.892 & 0.905 & 0.906 & 0.895 \\
& $(0.021)$ & $(0.023)$ & $(0.018)$ & $(0.017)$ & $(0.021)$ \\
\hline $\mathrm{J}$ & 42.244 & 46.618 & 40.843 & 38.885 & 43.839 \\
& $(9.549)$ & $(12.866)$ & $(9.860)$ & $(9.230)$ & $(11.316)$ \\
\hline $\mathrm{N}$ & 0.291 & 0.185 & 0.075 & 0.466 & 0.042 \\
{$[0.590]$} & {$[0.667]$} & {$[0.785]$} & {$[0.495]$} & $0.838]$ \\
\hline
\end{tabular}

The parameter $\theta$ is the irreversibility premium. The parameter $\zeta$ captures the combined effects of non-constant returns to scale and imperfect competition. The parameter $\alpha$ governs the adjustment cost technology. Standard errors are in parentheses under the parameter estimates. The $\mathrm{J}$ statistic is the Hansen $\mathrm{J}$ statistic for testing overidentifying restrictions (with $\mathrm{p}$-values in brackets). The statistic $\mathrm{N}$ is the number of firm/year observations. Parameter estimates are based on equation (20) with the definitions in equations (21) and (22). The estimation method is GMM with the following instruments: SALES/K, I/K, $1+r+\delta, p^{I} / p^{Y}$ (all for the previous period and adjusted for taxes), and an indicator variable $\left(\Gamma_{\mathrm{t}}\right)$ identifying a class of observations likely to face a binding irreversibility constraint (listed at the top of the column). Section 4.2 and the Data Appendix contain definitions, sources, and details about the construction of the variables, and Section 6 contains precise definitions of the classes. 
First, the irreversibility premium tends to be higher when several variables combine to increase the likelihood that a firm will face a binding irreversibility constraint. For example, when there are limited resale markets and low depreciation rates, the estimated irreversibility premium is 500 basis points, as shown in the first column of Table $4 \mathrm{a}$. When limited resale markets and low depreciation are combined with high demand uncertainty, the irreversibility premium rises to 1360 basis points, as shown in the first column of Table 5.

Second, the magnitude of the irreversibility premium is substantial. For example, when a firm with limited resale markets and a low depreciation rate is hit by a negative industry-wide shock, the irreversibility premium is $17.4 \%$. This is large in comparison with time series fluctuations in the risk-free real interest rate, which rarely varies by more than $10 \%$ over the course of a business cycle. ${ }^{15}$ It is noteworthy that the estimated irreversibility premium is particularly high when it is measured using a combination of negative industry-wide shocks and characteristics such as limited resale markets and low depreciation rates that make it difficult to eliminate excess capital. An implication of the estimates of the irreversibility premium from Table 5 is that monetary and other shocks can have a much larger effect on investment than is implied by standard estimates of the user cost elasticity, because the effective discount rate varies much more than the measured real interest rate. The estimates of the irreversibility premium from Table 5 also imply that non-convex adjustment frictions play an economically important role in investment fluctuations.

\section{Irreversibility and Finance Constraints}

Non-convex adjustment costs are not the only friction that could affect the shadow discount rate. There is a substantial literature on finance constraints and their implications for investment. ${ }^{16}$ Whited (1992) is a pioneering paper that shows how investment Euler equations

\footnotetext{
${ }^{15}$ For example, one of the largest increases in the risk-free real interest rate took place during the Volcker disinflation, when the mean real interest rate rose from around $-2 \%$ to $6 \%$. (See, e.g., Garcia and Perron (1996), who estimate the mean real interest rate in a regime-switching framework over the period 1961 1986.)

${ }^{16}$ Fazzari, Hubbard, and Petersen (1988) is a pioneering paper in the modern literature on finance constraints and investment. Hubbard (1998) provides a survey. Whited and $\mathrm{Wu}(2006)$ is a recent paper that contains many additional references to the literature. See Section 2 for additional references to papers that use investment Euler equations to test for finance constraints.
} 
can be used to test for finance constraints. In this section, we examine whether non-convex adjustment costs, finance constraints, or both affect the shadow discount rate.

The theoretical literature on finance constraints is based on the idea that there may be important information asymmetries between firms and potential providers of external finance. ${ }^{17}$ This literature suggests that the firms that are the most likely to be finance constrained are firms with good investment opportunities that have difficulty credibly communicating private information about these investment opportunities. Young firms are often cited as being particularly prone to information asymmetries and are therefore more likely to face finance constraints. In estimating the effect of finance constraints, we therefore focus on young firms with good investment opportunities (as measured by Tobin's Q).

We estimate the external finance premium using a technique that is similar to the technique used in estimating the irreversibility premium. Specifically, we expand the discount rate in equations (17), (19), and (20a) from $r_{t}$ to $r_{t}+\phi_{t}$, where $\phi_{t}$ is the external finance premium. We then estimate $\phi_{t}$ as $\phi \Psi_{t}$, where $\Psi_{t}$ is an indicator variable that is set equal to 1 for young firms with good investment opportunities. ${ }^{18}$ We use the same instruments that we have used previously for the non-convex adjustment cost model, except that we add $\Psi_{t}$.

The first column of Table 6 reports that the external finance premium is estimated as 1300 basis points (with a standard error of 210 basis points). The second column of Table 6 reports the irreversibility premium (based on observations with low depreciation rates). We focus initially on low depreciation rates since we are unaware of any paper in the substantial literature on finance constraints that has ever suggested that low depreciation rates would increase the likelihood of finance constraints. The third column of the table reports estimates from a specification that includes both $\theta$ and $\phi$. Neither the estimated irreversibility premium nor the estimated external finance premium is much affected by the inclusion of both $\theta$ and $\phi$. The estimated irreversibility premium rises from 220 to 250 basis points. The estimated external

\footnotetext{
${ }^{17}$ See, e.g., Stiglitz and Weiss (1981) on debt markets and Myers and Majluf (1984) on equity markets. Bernanke and Gertler (1989) and Bernanke, Gertler, and Gilchrist (1999) are among the papers that discuss the macroeconomic implications of asymmetric information in external finance markets.

${ }^{18} \mathrm{~A}$ firm is classified as having good investment opportunities for a given year if beginning-of-period Tobin's Q is above the median for all firms in that year. A firm is classified as young if it has been in the sample for 10 years or less.
} 
Table 6

Irreversibility and Finance Constraints

\begin{tabular}{|l|c|c|c|}
\hline & $\begin{array}{c}\text { Model with } \\
\text { Finance Constraints }\end{array}$ & $\begin{array}{c}\text { Model with } \\
\text { Irreversibility }\end{array}$ & $\begin{array}{c}\text { Model with } \\
\text { Irreversibility and } \\
\text { Finance Constraints }\end{array}$ \\
\hline$\theta$ & & 0.022 & 0.025 \\
& & $(0.008)$ & $(0.008)$ \\
\hline$\phi$ & 0.130 & & 0.132 \\
& $(0.021)$ & & $(0.021)$ \\
\hline $\mathrm{J}$ & 0.484 & 0.024 & 0.841 \\
& {$[0.487]$} & {$[0.876]$} & {$[0.359]$} \\
\hline $\mathrm{N}$ & 49,796 & 60,287 & 49,796 \\
\hline
\end{tabular}

The row labeled $\theta$ reports estimates of the irreversibility premium. The row labeled $\phi$ reports estimates of the external finance premium. In the column "Model with Finance Constraints," the external finance premium is captured by allowing young firms with good investment opportunities (characteristics associated with a higher likelihood of finance constraints in theoretical models) to have a different intertemporal discount rate than other firms. Similarly, in the column "Model with Irreversibility," firms with low depreciation rates are allowed to have a different intertemporal discount rate. The column "Model with Irreversibility and Finance Constraints" allows for both an irreversibility premium and an external finance premium, with each identified in the same way as in the two previous columns. The J statistic is the Hansen J statistic for testing overidentifying restrictions (with $\mathrm{p}$-values in brackets). The statistic $\mathrm{N}$ is the number of firm/year observations. In each column, all observations with the necessary data are included in the sample. Standard errors are in parentheses under the parameter estimates. Except for inclusion of the external finance premium in the specification (and the corresponding instrument), estimation and instruments are similar to those for Tables 3-5; for additional details, see Section 7.

not the specification allows for an external finance premium. In the case of negative industrywide shocks, the estimated irreversibility premium is approximately 500 basis points whether or finance premium rises from 1300 to 1320 basis points. The standard errors of both the irreversibility premium and the external finance premium are unaffected.

Table 7 examines two further variables that are likely to be associated with irreversibility -- high demand uncertainty and negative industry-wide shocks. If these variables were simply proxies for finance constraints, the inclusion of an explicit measure of finance constraints could be expected to substantially diminish the estimated magnitude and statistical significance of the 
Table 7

Irreversibility and Finance Constraints Alternative Measures of Irreversibility

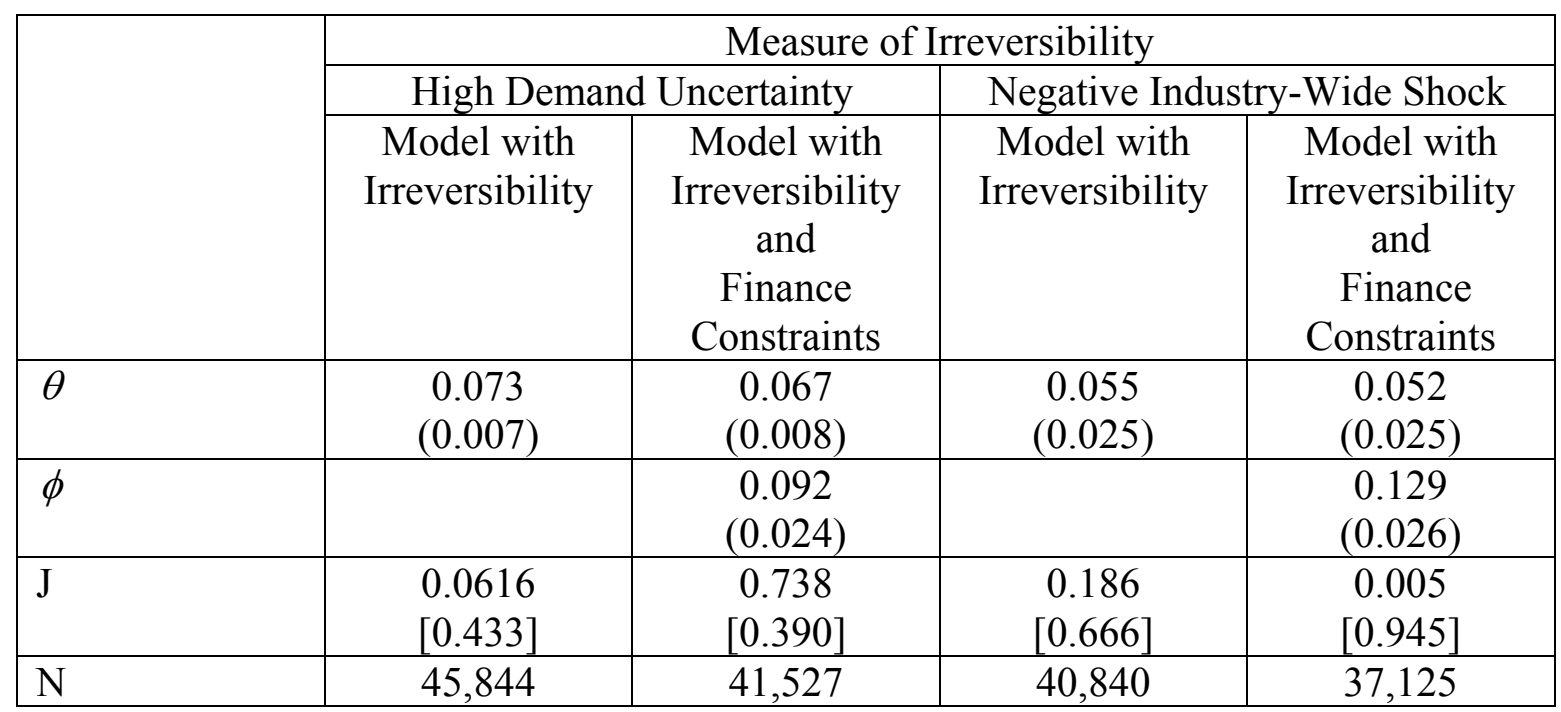

The row labeled $\theta$ reports estimates of the irreversibility premium. The row labeled $\phi$ reports estimates of the external finance premium. Standard errors are in parentheses under the parameter estimates. The table reports results for two measures of the likelihood of facing a binding irreversibility constraint. Under the heading "High Demand Uncertainty," $\Gamma_{\mathrm{t}}=1$ for observations with high demand uncertainty. Under the heading "Negative Industry-Wide Shock," $\Gamma_{\mathrm{t}}=1$ for observations with negative industry-wide shocks. In the columns "Model with Irreversibility and Finance Constraints," the external finance premium is captured by allowing young firms with good investment opportunities (characteristics associated with a higher likelihood of finance constraints in theoretical models) to have a different intertemporal discount rate than other firms. The $\mathrm{J}$ statistic is the Hansen $\mathrm{J}$ statistic for testing overidentifying restrictions (with p-values in brackets). The statistic $\mathrm{N}$ is the number of firm/year observations. In each column, all observations with the necessary data are included in the sample. Except for inclusion of the external finance premium in the specification (and the corresponding instrument), estimation and instruments are similar to those for Tables 3-5; for additional details, see Section 7.

irreversibility premium. In the data, this does not occur. In the case of high demand uncertainty, the estimated irreversibility premium is approximately 700 basis points, regardless of whether or not the specification allows for an external finance premium. In both cases, the external finance premium remains substantial (about 900 basis points in the first case and about 1300 basis points in the second case), and the standard error of the estimated irreversibility premium is essentially unchanged. 
The empirical results in Tables 6 and 7 suggest that both non-convex adjustment costs and financial frictions have substantial effects on the effective discount rate.

\section{Investment Regimes}

In Abel and Eberly (1994), there are three investment regimes - positive investment, zero investment, and negative investment. The non-convex adjustment cost model described in Section 3, which is based on the Abel and Eberly model, also involves three investment regimes. In this section, we examine whether the model provides a good fit to the data for each of these investment regimes.

For non-positive investment, the model implies that equation (17) is replaced by equation (19). Since $\omega_{t}$ is not directly observable, it appears in the error term along with the technology shock $\left(\varepsilon_{t}\right)$ and the expectational error $\left(v_{t}\right)$, as shown in equation (20). For the sample as a whole, the presence of $\omega_{t}$ in the error term does not lead to a rejection of the non-convex adjustment cost model, as illustrated in the first column of Table 8 (for five different characteristics that affect the irreversibility premium). The $\mathrm{J}$ test fails to reject the Euler equation.

The second column examines the observations with positive investment. For these observations, $\omega_{\mathrm{t}}$ does not enter the error term, and the $\mathrm{J}$ test again fails to reject the Euler equation at the 5\% level of significance. Interestingly, there is no systematic difference in the level of the J statistics, compared to the first column. In some cases, the J statistic rises; in others, it falls.

The third and fourth columns provide the sharpest test, focusing only on non-positive investment observations for which $\omega_{\mathrm{t}}$ is present in the error term. Again, the J statistic is higher in some cases (compared to the first column), while in other cases it is lower. There are no cases where the model is rejected when investment is zero or negative. The failure to reject the nonconvex adjustment cost model does not seem to arise from a lack of power, since the convex adjustment cost model is strongly rejected, as shown earlier in the first row of Table 2. 
Table 8

Investment regimes

\begin{tabular}{|c|c|c|c|c|c|c|c|c|}
\hline & \multicolumn{2}{|c|}{ Full Sample } & \multicolumn{2}{|c|}{$\begin{array}{c}\text { Positive } \\
\text { Investment }\end{array}$} & \multicolumn{2}{|c|}{ Zero Investment } & \multicolumn{2}{|c|}{$\begin{array}{l}\text { Negative } \\
\text { Investment }\end{array}$} \\
\hline & $\mathrm{N}$ & $\mathrm{J}$ & $\mathrm{N}$ & $\mathrm{J}$ & $\mathrm{N}$ & $\mathrm{J}$ & $\mathrm{N}$ & $\mathrm{J}$ \\
\hline $\begin{array}{l}\text { Limited } \\
\text { Resale } \\
\text { Markets }\end{array}$ & 59908 & $\begin{array}{c}0.550 \\
{[0.458]}\end{array}$ & 59241 & $\begin{array}{c}1.833 \\
{[0.176]}\end{array}$ & 281 & $\begin{array}{c}3.558 \\
{[0.059]}\end{array}$ & 386 & $\begin{array}{c}1.853 \\
{[0.173]}\end{array}$ \\
\hline $\begin{array}{l}\text { Low } \\
\text { Depreciation } \\
\text { Rate }\end{array}$ & 60287 & $\begin{array}{c}0.024 \\
{[0.876]}\end{array}$ & 59610 & $\begin{array}{c}0.168 \\
{[0.682]}\end{array}$ & 284 & $\begin{array}{c}3.608 \\
{[0.057]}\end{array}$ & 393 & $\begin{array}{c}1.181 \\
{[0.277]}\end{array}$ \\
\hline $\begin{array}{l}\text { High } \\
\text { Demand } \\
\text { Uncertainty }\end{array}$ & 45844 & $\begin{array}{c}0.616 \\
{[0.433]}\end{array}$ & 45467 & $\begin{array}{c}0.121 \\
{[0.728]}\end{array}$ & 60 & $\begin{array}{c}0.458 \\
{[0.498]}\end{array}$ & 317 & $\begin{array}{c}0.115 \\
{[0.734]}\end{array}$ \\
\hline $\begin{array}{l}\text { High } \\
\text { Cost } \\
\text { Uncertainty }\end{array}$ & 45844 & $\begin{array}{c}0.444 \\
{[0.505]}\end{array}$ & 45467 & $\begin{array}{c}0.052 \\
{[0.820]}\end{array}$ & 60 & $\begin{array}{c}0.414 \\
{[0.520]}\end{array}$ & 317 & $\begin{array}{c}0.131 \\
{[0.717]}\end{array}$ \\
\hline $\begin{array}{l}\text { Negative } \\
\text { Industry- } \\
\text { wide Shocks }\end{array}$ & 40840 & $\begin{array}{c}0.186 \\
{[0.666]}\end{array}$ & 40506 & $\begin{array}{c}0.780 \\
{[0.377]}\end{array}$ & 52 & $\begin{array}{c}0.343 \\
{[0.558]}\end{array}$ & 282 & $\begin{array}{c}0.318 \\
{[0.573]}\end{array}$ \\
\hline
\end{tabular}

The $\mathrm{J}$ statistic is the Hansen $\mathrm{J}$ statistic for testing overidentifying restrictions (with p-value in brackets). The statistic $\mathrm{N}$ is the number of firm/year observations. In all cases, all observations with the necessary data are included in the sample. The rows reflect different choices of $\Gamma_{\mathrm{t}}$, with $\Gamma_{\mathrm{t}}$ set equal to 1 for observations with the characteristic shown in the row heading, where $\Gamma_{\mathrm{t}}$ is an indicator variable identifying a class of observations likely to face a binding irreversibility constraint.

\section{Summary and conclusions}

Irreversibility - or, more generally, non-convex adjustment costs - has important economic implications. Firm dynamics become more complicated. With irreversible capital, investment behavior becomes path dependent (Dixit, 1992), and aggregate investment depends on the higher moments of firm characteristics (Caballero, 1999). Many tax distortions are amplified by irreversibilties (Faig and Shum, 1999; Panteghini, 2001). Irreversible investment decisions change the nature of the inefficiencies arising from asymmetric information in capital markets (Lensink, Bo, and Sterken, 2001). Insofar as monetary policy affects uncertainty, irreversible capital can create an additional channel through which monetary policy and inflationary shocks impact the real economy (Pindyck and Soliamanos, 1993). 
The irreversibility premium addresses the high hurdle rates puzzle posed by Dixit (1992). A variety of surveys suggest that managers use a discount rate that is substantially higher than the market discount rate. For example, Poterba and Summers (1995) report that hurdle rates are "distinctly higher than equity holders' average rates of return and much higher than the return on debt during the past half-century" (p. 43). Their average real hurdle rate of $12.2 \%$ substantially exceeds the real weighted-average market discount rate of $6.6 \% .{ }^{19}$ Thus, the high hurdle rate puzzle is approximately 560 basis points. While several explanations have been offered to explain relatively high hurdle rates, the higher discount rates due to irreversibility may be a contributing factor, as suggested by Dixit (1992).

A variety of empirical studies have examined whether irreversibility exists. In this paper, we make a distinctive contribution to this evidence by estimating the irreversibility premium, a readily interpretable measure of the economic importance of non-convex adjustment costs. The evidence presented here suggests that the irreversibility premium is both economically and statistically significant.

\footnotetext{
${ }^{19}$ The latter figure is a long-run weighted-average of debt and equity returns (adjusted for inflation) for the United States taken from Poterba (1998, p. 235).
} 


\section{References}

Abel, Andrew B., and Eberly, Janice E., “A Unified Model Of Investment Under Uncertainty," American Economic Review 84 (December 1994), 1369-1384.

Abel, Andrew B., and Eberly, Janice E., "Investment And q With Fixed Costs," University of Pennsylvania (January 1996a).

Abel, Andrew B., and Eberly, Janice E., "Optimal Investment With Costly Reversibility," Review Of Economic Studies 63 (October 1996b), 581-594.

Abel, Andrew B., and Eberly, Janice E., “The Effects Of Irreversibility And Uncertainty On Capital Accumulation," Journal Of Monetary Economics_44 (December 1999), 339-378.

Andrews, Donald W. K., and Lu, Biao, "Consistent model and moment selection procedures for GMM estimation with application to dynamic panel data models," Journal of Econometrics (2001) 101, 123-164.

Arrow, Kenneth J., "Optimal Capital Policy with Irreversible Investment," in J.N. Wolfe (ed.), Value, Capital, and Growth (Edinburgh: Edinburgh University Press, 1968), 1-20; reprinted in Production and Capital: Collected Papers of Kenneth J. Arrow Vol. 5 (Cambridge: Harvard University Press, 1985), 241-260.

Asplund, Marcus, "What Fraction of a Capital Investment Is Sunk Costs?," The Journal of Industrial Economics 48 (September 2000), 287-304.

Barnett, Steven A., and Sakellaris, Plutarchos, "Nonlinear Response Of Firm Investment To Q: Testing A Model Of Convex And Non-Convex Adjustment Costs," Journal Of Monetary Economics 42 (October 1998), 261-288.

Bernanke, Benjamin S., "Irreversibility, Uncertainty, and Cyclical Investment," Quarterly Journal of Economics 98 (February 1983), pp. 85-106.

Bernanke, Benjamin S., and Gertler, Mark, "Agency Costs, Net Worth, and Business Fluctuations," The American Economic Review (1989) 79, 14-31.

Bernanke, Benjamin S., Gertler, Mark, and Gilchrist, Simon, "The Financial Accelerator in a Quantitative Business Cycle Framework," in J. B. Taylor and M. Woodford (ed), Handbook of Macroeconomics, Vol. 1, Chapter 21, 1341-1393 (Elsevier, 1999).

Bertola, Giuseppe, and Caballero, Ricardo J., "Irreversibility and Aggregate Investment," Review of Economic Studies 61 (April 1994), 223-246.

Bloom, Nicholas, “The Impact of Uncertainty Shocks,” NBER Working Paper 13385, September 2007. 
Bloom, Nicholas, Bond, Stephen, and van Reneen, John, "Uncertainty and Investment Dynamics," Review of Economic Studies (2007) 74, 391-415.

Bo, Hong, Lensink, Robert, and Sterken, Elmer, "Investment, Cash Flow, and Uncertainty: Evidence for the Netherlands," CCSO Working Papers 200114, 2001.

Bond, Stephen, and Meghir, Costas, "Dynamic Investment Models and the Firm's Financial Policy,” Review of Economic Studies (1994) 61, 197-222.

Butzen, P.C., Fuss, Catherine, and Vermuelen, Philip, "The Impact of Uncertainty on Investment Plans," in P.C. Butzen and C. Fuss (eds.), Firms' Investment and Finance Decisions: Theory and Empirical Methodology (Cheltenham, U.K.: Edward Elgar, 2003).

Caballero, Ricardo J., “Aggregate Investment,” in John B. Taylor and Michael Woodford (eds.), Handbook Of Macroeconomics, Volume 1B (Amsterdam: Elsevier North-Holland), 1999), 813-862.

Caballero, Ricardo J., and Engel, Eduardo M.R.A., "Explaining Investment Dynamics in U.S. Manufacturing: A Generalized (S,s) Approach," Econometrica, 67 (1999), 783-826.

Caballero, Ricardo J., Engel, Eduardo M.R.A., and Haltiwanger, John C., "Plant-Level Adjustment and Aggregate Investment Dynamics," Brookings Papers on Economic Activity (1995:2), 1-54.

Caballero, Ricardo J., and Pindyck, Robert S., "Uncertainty, Investment, and Industry Evolution," International Economic Review 37 (1996), 641-662.

Chirinko, Robert S., Fazzari, Steven M., and Meyer, Andrew P., "How Responsive Is Business Capital Formation To Its User Cost?: An Exploration With Micro Data," Journal of Public Economics 74 (October 1999), 53-80.

Chirinko, Robert S., and Schaller, Huntley (2004a), “A revealed preference approach to understanding corporate governance problems: Evidence from Canada," Journal of Financial Economics 74 (October 2004), 181-206.

Chirinko, Robert S., and Schaller, Huntley (2004b), “The Initial Value Problem,” Emory University and Carleton University (June 2004).

Cooper, Russell W., and Haltiwanger, John C., "On The Nature Of Capital Adjustment Costs,” Review of Economic Studies 73 (2006), 611-633.

Dixit, Avinash, "Investment and Hysteresis," The Journal of Economic Perspective 6 (Winter 1992), 107-132. 
Dixit, Avinash K., and Pindyck, Robert S., Investment Under Uncertainty (Princeton: Princeton University Press, 1994).

Eberly, Janice C., "International Evidence on Investment and Fundamentals," European Economic Review 41 (June 1997), 1055-1078.

Faig, Miquel, and Shum, Pauline, "Irreversible Investment And Endogenous Financing: AN Evaluation Of The Corporate Tax Effects," Journal Of Monetary Economics 43 (February 1999), 143-172.

Fazzari, S., Hubbard, R., and Petersen, B., "Financing Constraints and Corporate Investment," Brookings Papers on Economic Activity (1988) 1, 141-195.

Garcia, René, and Perron, Pierre, "An Analysis of the Real Interest Rate Under Regime Shifts," The Review of Economics and Statistics (1996) 78, 111-125.

Ghosal, Vivek, and Loungani, Prakash, "The Differential Impact of Uncertainty of Investment in Small and Large Businesses," The Review of Economics and Statistics 82 (May 2000), 338-343.

Guiso, Luigi, and Parigi, Giuseppe, "Investment And Demand Uncertainty," Quarterly Journal Of Economics 114 (February 1999), 185-228.

Goolsbee, Austan and Gross, David B., "Estimating Adjustment Costs With Data On Heterogeneous Capital Goods,” University of Chicago (February 1997).

Hubbard, R. G., "Capital-Market Imperfections and Investment," Journal of Economic Literature (1998) 36, 193-225.

Hubbard, R. G., and Kashyap, A. K., "Internal Net Worth and the Investment Process: An Application to U.S. Agriculture," Journal of Political Economy (1992) 100, 506-434.

Hubbard, R. G., Kashyap, A. K., and Whited, T. M., "Internal Finance and Firm Level Investment,” Journal of Money, Credit, and Banking (1995), 27: 683-701.

von Kalckreuth, Ulf, "Exploring the Role of Uncertainty for Corporate Investment Decisions in Germany," Swiss Journal of Economics and Statistics 139 (June 2003), 173-206.

Leahy, John V., and Whited, Toni M., “The Effect of Uncertainty on Investment: Some Stylized Facts," Journal of Money, Credit, and Banking 28 (1996), 65-83.

Lensink, Robert, Bo, Hong, and Sterken, Elmer, Investment, Capital Market Imperfections, and Uncertainty: Theory and Empirical Results (Cheltenham, UK: Edward Elgar, 2001). 
Love, Inessa, "Financial Development and Financing Constraints: International Evidence from the Structural Investment Model," Review of Financial Studies (2003), 16, 765-791.

Myers, Stewart C., and Majluf, Nicholas S., "Corporate financing and investment decisions when firms have information that investors do not have," Journal of Financial Economics (1984), 13: 187-221.

Ng, Serena, and Schaller, Huntley, “The Risky Spread, Investment, and Monetary Policy Transmission: Evidence on the Role of Asymmetric Information," The Review of Economics and Statistics (1996) 78, 375-383.

Nickell, Stephen J., The Investment Decisions of Firms (Cambridge: Cambridge University Press, 1978).

Panteghini, Paolo, "On Corporate Tax Asymmetries And Neutrality," German Economic Review 2 (August 2001). 269-286

Pechman, Joseph A., Federal Tax Policy, Fifth Edition (Washington: Brookings Institution, 1987).

Pindyck, Robert S., and Solimano, Andrés, "Economic Instability and Aggregate Investment," in Olivier J. Blanchard and Stanley Fischer (eds.), NBER Macroeconomics Annual (Cambridge: MIT Press, 1993), 259-303.

Poterba, James M., "The Rate of Return to Corporate Capital and Factor Shares: New Estimates Using Revised National Income Accounts and Capital Stock Data," CarnegieRochester Conference Series on Public Policy 48 (June 1998), 211-246.

Poterba, James M., and Summers, Lawrence H., "A Survey of U.S. Companies, Time Horizons, and Hurdle Rates,” Sloan Management Review 37 (1995), 43-53.

Ramey, Valerie A., and Shapiro, Matthew D., "Displaced Capital: A Study of Aerospace Plant Closings," Journal of Political Economy 109 (October 2001), 958-992.

Shapiro, Matthew, “The Dynamic Demand for Capital and Labor," Quarterly Journal of Economics (1986) 101, 513-542.

Shleifer, Andrei, and Vishny, Robert W., "Liquidation Values and Debt Capacity: A Market Equilibrium Approach," The Journal of Finance (1992) 47, 1343-1366.

Stiglitz, Joseph E., and Weiss, Andrew, "Credit Rationing in Markets with Imperfect Information,” The American Economic Review (1981) 71, 393-410.

Temple, Paul, Urga, Giovanni, and Driver, Ciaran, "The Influence of Uncertainty on Investment in the UK: A Macro or Micro Phenomenon?," Scottish Journal of Political Economy 48 (September 2001), 361-382. 
Whited, Toni M., "Debt, Liquidity Constraints, and Corporate Investment: Evidence from Panel Data," Journal of Finance (1992), 47: 1425-1460.

Whited, Toni M., "Why do Investment Euler Equations Fail?" Journal of Business and Economic Statistics (1998), 16: 479-488.

Whited, Toni M., and Wu, Guojun, "Financial Constraints Risk," Review of Financial Studies (2006), 19(2): 531-559. 


\section{Data Appendix}

This Data Appendix presents details about the construction of the capital stock and investment flow series, the tax-adjusted relative price of investment goods, and the real riskadjusted market discount rate.

\section{A. Capital Stock and Investment Flows}

For the first observation for firm $\mathrm{f}$, the capital stock is based on the net plant (NPLANT), the nominal book value of net property, plant, and equipment (CompuStat item 8). To convert this to real terms, we divide by the sector-specific price index for investment $\left(p^{\mathrm{I}}\right)$. Since book value is not adjusted for changes in the value of capital goods purchased in the past, we adjust the initial capital stock using a sector-specific adjustment factor (AF):

$$
K_{f, t_{0}^{f}}=\frac{N P L A N T_{f, t_{0}^{f}}}{p_{s, t_{0}^{f}}^{I}} A F_{s}
$$

where $\mathrm{s}$ is a sector index (for firm f's sector) and $t_{0}^{f}$ is the year of the first observation for firm $\mathrm{f}$.

Failure to adjust book value affects the initial value of the capital stock, but has a geometrically decreasing impact on the measured capital stock over time. After 15 years, the initial value effect is negligible. We use this fact to construct the adjustment factor for the initial value of the capital stock. For sector s, AF is the ratio of the mean unadjusted capital stock for firms of age 15 or greater to the mean of what the unadjusted capital stock would have been measured as, if t equaled $t_{0}^{f}$ (i.e., if the current year were the firm's first year in the sample). In effect, AF is the ratio of the true capital stock to the unadjusted initial value. Additional details are available in Chirinko and Schaller (2004b).

For subsequent observations, a standard perpetual inventory method is used to construct the capital stock,

$$
K_{f, t+1}=\left(1-\delta_{s, t}\right) K_{f, t}+\frac{K C H G_{f, t+1}}{p_{s, t+1}^{I}}
$$


where $\delta$ is the depreciation rate, $\mathrm{KCHG}$ is gross additions to the firm's capital stock and, in this Data Appendix, the capital stock is dated at the end of the period. The firm reports the additions in nominal terms, so we divide by $\mathrm{p}^{\mathrm{I}}$ to convert to real terms.

In the standard case, $\mathrm{KCHG}$ is gross investment (GI), which is capital expenditures in the firm's financial statements (CompuStat item 128). CompuStat does not always have reliable data for the additions to the capital stock associated with large acquisitions. We use a modified version of the algorithm of Chirinko, Fazzari, and Meyer (1999) to adjust KCHG for acquisitions and divestitures. In the case of a substantial acquisition, we can use accounting identities to derive a more accurate measure of the additions to the capital stock,

$\operatorname{DGPLANT}_{f, t}=G I_{f, t}+$ ACQUIS $_{f, t}-\operatorname{RETIRE}_{f, t}$

where DGPLANT $\mathrm{t}_{\mathrm{t}}$ is the change in GPLANT from the end of year $\mathrm{t}-1$ to the end of year $\mathrm{t}$ and GPLANT $_{\mathrm{t}}$ is gross property, plant, and equipment (CompuStat item 7), ACQUIS is acquisitions, and RETIRE is retirements of capital stock (CompuStat item 184). (When data on RETIRE is missing, we assume that the reason is that firms do not report any retirements in their financial statements, and we therefore assign a value of 0 to RETIRE for these observations.) We use the following screen to identify cases where there has been a substantial acquisition. If

$\frac{\operatorname{DGPLANT}_{f, t}-G I_{f, t}}{G P L A N T_{f, t-1}}>0.1$

then we calculate the gross change in the capital stock as

$\mathrm{KCHG}_{t}=\mathrm{DGPLANT}_{t}+\mathrm{RETIRE}_{t}$

We also account for substantial divestitures, using the following screen. If

$\frac{\operatorname{DGPLANT}_{f, t}+\operatorname{RETIRE}_{f, t}}{G P L A N T_{f, t-1}}<-0.1$ 
we calculate the change in the capital stock as

$\mathrm{KCHG}_{f, t}=\mathrm{DNPLANT}_{f, t}+\delta K_{f, t-1} p_{s, t}^{I}$

where DNPLANT is the change in NPLANT (as defined above). ${ }^{20}$ Because NPLANT in the firm's financial statements will deduct depreciation (as well as accounting for the divestiture), depreciation must be added to $\mathrm{KCHG}$ to avoid deducting depreciation twice.

If $G P L A N T_{f, t-1}$ is missing (or equal to zero) or $D G P L A N T_{f, t}$ is missing, it is not feasible to use these screens, and we set KCHG equal to GI.

In some cases, there is a data gap for a particular firm. In this case, we treat the first new observation for that firm in the same way as we would if it were the initial observation. This avoids any potential sample selection bias that would result from dropping firms with gaps in their data.

Investment (I) is defined by KCHG.

We construct sector-specific, time-varying depreciation rates using data from the BEA. Specifically,

$\delta_{s, t}=\frac{D \$_{s, 1996} D Q U A N T_{s, t}}{K \$_{s, 1996} K Q U A N T_{s, t}}$

where D\$ is current-cost depreciation of private fixed assets by sector (BEA, Table 3.4ES), DQUANT is the chain-type quantity index of depreciation of private fixed assets by sector (BEA, Table 3.5ES), $\mathrm{K} \$$ is the current cost net stock of private fixed assets by sector (as defined

${ }^{20}$ To see this result, start with the perpetual inventory equation.

$K_{t}=I_{t}+(1-\delta) K_{t-1}$

$K_{t}-K_{t-1}+\delta K_{t-1}=I_{t}$

Now, put the previous equation in nominal terms.

$\left[K_{t}-K_{t-1}\right] p_{t}^{I}+\delta K_{t-1} p_{t}^{I}=I_{t} p_{t}^{I}$

$D N P L A N T_{t}+\delta K_{t-1} p_{t}^{I}=I_{t} p_{t}^{I}=K C H G_{t}$ 
above), and KQUANT is the chain-type quantity index of the net stock of private fixed assets by sector (BEA, Table 3.2ES).

We construct the sector-specific price index for new investment goods using BEA data:

$$
p_{s, t}^{I}=\frac{100\left(I \$_{s, t} / I \$_{s, 1996}\right)}{I Q U A N T_{s, t}}
$$

where I\$ is historical-cost investment in private fixed assets by sector (BEA, Table 3.7ES) and IQUANT is the chain-type quantity index of investment in private fixed assets by sector (BEA, Table 3.8ES).

\section{B. The Tax-adjusted relative price of investment goods}

The relative price of investment, $\mathrm{rp}$, is adjusted for corporate income taxes and defined as follows,

$$
\mathrm{rp}=\left(\mathrm{p}^{\mathrm{I}} / \mathrm{p}^{\mathrm{Y}}\right)(1-\mathrm{itc}-\mathrm{z})
$$

where $\mathrm{p}^{\mathrm{I}}$ is the sector-specific price deflator for new investment goods defined above, $\mathrm{p}^{\mathrm{Y}}$ is the sector-specific price index for output defined as the implicit price deflator for Gross Domestic Product by industry produced by the BEA (normalized to 1 in 1996), itc is the investment tax credit rate, and $\mathrm{z}$ is the present value of depreciation allowances.

Where variables are available at a monthly or quarterly frequency, we take the average for the calendar year. The investment tax credit rates are drawn from Pechman (1987, p.160161). Because the investment tax credit applies only to equipment, the investment tax credit for structures is zero; we multiply the statutory ITC rate for each year by the ratio of equipment investment to the sum of structures and equipment investment for that year. The present value of depreciation allowances - for non-residential equipment and structures, respectively - were provided by Dale Jorgenson. To calculate z, we took the weighted sum of Jorgenson's z's for equipment and structures, where the weights are the share of equipment investment and the share of structures investment (for a given year) in nominal gross private non-residential investment in 
fixed assets from the Bureau of Economic Analysis (Table 1IHI, where equipment investment is referred to as equipment and software).

\section{The Real Risk-Adjusted Market Discount Rate}

The real, risk-adjusted market discount rate is defined as follows,

$$
r_{f, t}=\left(\left(1+r_{f, t}^{N O M}\right) /\left(1+\pi_{t}^{e}\right)\right)-1.0
$$

The equity risk premium is calculated using CAPM. The components of $r_{f, t}$ are defined and constructed as follows,

$$
\begin{aligned}
& r_{f, t}^{N O M} \quad=\quad \text { Nominal, short-term, risk-adjusted cost of capital } \\
& =\quad \lambda_{\mathrm{s}}\left(1-\tau_{\mathrm{t}}\right) r_{t}^{\mathrm{NOM}, D E B T}+\left(1-\lambda_{\mathrm{s}}\right) r_{s, t}^{N O M, E Q U I T Y} \text {. } \\
& r_{t}^{N O M, D E B T}=\quad \text { Nominal corporate bond rate (Moody's Seasoned Baa } \\
& \text { Corporate Bond Yield) } \\
& r_{s, t}^{N O M, E Q U I T Y}=\quad \text { Nominal, short-term, risk-adjusted cost of equity capital for } \\
& \text { firms in sector s. } \\
& =r_{t}^{N O M, F}+\sigma_{\mathrm{s}} \text {. }
\end{aligned}
$$

$r_{t}^{\text {NOM }, F}=\quad$ Nominal, one-year, risk-free rate (One-Year Treasury Constant Maturity Rate)

$\pi_{s, t}^{e} \quad=\quad$ Sector-specific capital goods price inflation rate from $\mathrm{t}$ to $\mathrm{t}+1$. Sectorspecific data was not yet available for 2002 at the time of data construction, so the inflation rate for nonresidential fixed investment was used for $\pi_{s, t}^{e}$ for 2001 .

$\sigma_{\mathrm{s}} \quad=\quad$ Equity risk premium.

$\tau_{\mathrm{t}} \quad=\quad$ Marginal rate of corporate income taxation.

$\lambda_{\mathrm{s}}=$ Sector-specific leverage ratio calculated as the mean of book debt for the sector divided by the mean of (book debt + book equity) for the sector. 
Under the CAPM,

$\sigma_{\mathrm{s}}=\beta_{\mathrm{s}}\left(\mu^{\mathrm{EQUITY}}-\mu^{\mathrm{F}}\right)$

where

$\beta_{\mathrm{s}} \quad=\quad \mathrm{CAPM} \beta$ for sector $\mathrm{s}$

$\mu^{\text {EQUITY }}=\quad$ Total return on equities from 1950-2001. The source is the valueweighted CRSP index (including dividends).

$\mu^{\mathrm{F}} \quad=\quad$ Total return on risk-free Treasury bills from 1950-2001. The source is the FRED database, specifically the series for 1-Year Treasury Constant Maturity Rate. 


\section{CESifo Working Paper Series}

for full list see www.cesifo-group.org/wp

(address: Poschingerstr. 5, 81679 Munich, Germany, office@cesifo.de)

2200 Andreas Bühn and Friedrich Schneider, MIMIC Models, Cointegration and Error Correction: An Application to the French Shadow Economy, January 2008

2201 Seppo Kari, Hanna Karikallio and Jukka Pirttilä, Anticipating Tax Change: Evidence from the Finnish Corporate Income Tax Reform of 2005, January 2008

2202 Walter Krämer and André Güttler, On Comparing the Accuracy of Default Predictions in the Rating Industry, January 2008

2203 Syed M. Ahsan and Panagiotis Tsigaris, The Efficiency Loss of Capital Income Taxation under Imperfect Loss Offset Provisions, January 2008

2204 P. Mohnen, F. C. Palm, S. Schim van der Loeff and A. Tiwari, Financial Constraints and other Obstacles: Are they a Threat to Innovation Activity?, January 2008

2205 Sascha O. Becker and Mathias Hoffmann, Equity Fund Ownership and the CrossRegional Diversification of Household Risk, January 2008

2206 Pedro R. D. Bom and Jenny E. Ligthart, How Productive is Public Capital? A MetaAnalysis, January 2008

2207 Martin Werding, Ageing and Productivity Growth: Are there Macro-level Cohort Effects of Human Capital?, January 2008

2208 Frederick van der Ploeg and Steven Poelhekke, Globalization and the Rise of MegaCities in the Developing World, February 2008

2209 Sara Biancini, Regulating National Firms in a Common Market, February 2008

2210 Jin Cao and Gerhard Illing, Liquidity Shortages and Monetary Policy, February 2008

2211 Mathias Kifmann, The Design of Pension Pay Out Options when the Health Status during Retirement is Uncertain, February 2008

2212 Laszlo Goerke, Tax Overpayments, Tax Evasion, and Book-Tax Differences, February 2008

2213 Jun-ichi Itaya and Heinrich W. Ursprung, Price and Death, February 2008

2214 Valentina Bosetti, Carlo Carraro and Emanuele Massetti, Banking Permits: Economic Efficiency and Distributional Effects, February 2008

2215 Assar Lindbeck, Mårten Palme and Mats Persson, Social Interaction and Sickness Absence, February 2008 
2216 Gary E. Bolton and Axel Ockenfels, The Limits of Trust in Economic Transactions Investigations of Perfect Reputation Systems, February 2008

2217 Hartmut Egger and Peter Egger, The Trade and Welfare Effects of Mergers in Space, February 2008

2218 Dorothee Crayen and Joerg Baten, Global Trends in Numeracy 1820-1949 and its Implications for Long-Run Growth, February 2008

2219 Stephane Dees, M. Hashem Pesaran, L. Vanessa Smith and Ron P. Smith, Identification of New Keynesian Phillips Curves from a Global Perspective, February 2008

2220 Jerome L. Stein, A Tale of Two Debt Crises: A Stochastic Optimal Control Analysis, February 2008

2221 Michael Melvin, Lukas Menkhoff and Maik Schmeling, Automating Exchange Rate Target Zones: Intervention via an Electronic Limit Order Book, February 2008

2222 Raymond Riezman and Ping Wang, Preference Bias and Outsourcing to Market: A Steady-State Analysis, February 2008

2223 Lars-Erik Borge and Jørn Rattsø, Young and Old Competing for Public Welfare Services, February 2008

2224 Jose Apesteguia, Steffen Huck, Jörg Oechssler and Simon Weidenholzer, Imitation and the Evolution of Walrasian Behavior: Theoretically Fragile but Behaviorally Robust, February 2008

2225 Walter Krämer, Long Memory with Markov-Switching GARCH, February 2008

2226 António Afonso and Christophe Rault, What do we really Know about Fiscal Sustainability in the EU? A Panel Data Diagnostic, February 2008

2227 Sergey M. Kadochnikov and Igor M. Drapkin, Market Structure, Technological Gap and Vertical Linkage Effects from Foreign Direct Investment, February 2008

2228 Guglielmo Maria Caporale, Davide Ciferri and Alessandro Girardi, Fiscal Shocks and Real Exchange Rate Dynamics: Some Evidence for Latin America, February 2008

2229 Scott Alan Carson, Geography and Insolation in $19^{\text {th }}$ Century US African-American and White Statures, February 2008

2230 Wolfgang Buchholz and Jan Schumacher, Discounting and Welfare Analysis Over Time: Choosing the $\eta$, February 2008

2231 M. Hashem Pesaran, Christoph Schleicher and Paolo Zaffaroni, Model Averaging in Risk Management with an Application to Futures Markets, February 2008

2232 Wilhelm Kohler, Offshoring: Why Do Stories Differ?, February 2008 
2233 Stefan Bach, Giacomo Corneo and Viktor Steiner, Effective Taxation of Top Incomes in Germany, 1992-2002, February 2008

2234 Robert S. Chirinko, $\sigma:$ The Long And Short Of It, February 2008

2235 Volker Grossmann and Holger Strulik, Should Continued Family Firms Face Lower Taxes than other Estates?, February 2008

2236 Guido Tabellini, The Scope of Cooperation: Values and Incentives, February 2008

2237 Heinrich W. Ursprung and Christian Wiermann, Reputation, Price, and Death: An Empirical Analysis of Art Price Formation, March 2008

2238 Hans Fehr and Christian Habermann, Private Retirement Savings in Germany: The Structure of Tax Incentives and Annuitization, March 2008

2239 Joseph Francois and Ian Wooton, Market Structure and Market Access, March 2008

2240 Hiroyuki Kasahara and Beverly Lapham, Productivity and the Decision to Import and Export: Theory and Evidence, March 2008

2241 Gary E. Bolton and Axel Ockenfels, Does Laboratory Trading Mirror Behavior in Real World Markets? Fair Bargaining and Competitive Bidding on EBay, March 2008

2242 Atsushi Oshima, B. Ravikumar and Raymond Riezman, Entrepreneurship, Organization Capital and the Evolution of the Firm, March 2008

2243 Walter Krämer and Sebastian Schich, Large-Scale Disasters and the Insurance Industry, March 2008

2244 Leif Danziger, Adjustment Costs, Inventories and Output, March 2008

2245 Anne van Aaken, Lars P. Feld and Stefan Voigt, Power over Prosecutors Corrupts Politicians: Cross Country Evidence Using a New Indicator, March 2008

2246 Hans-Christian Heinemeyer, Max-Stephan Schulze and Nikolaus Wolf, Endogenous Borders? The Effects of New Borders on Trade in Central Europe 1885-1933, March 2008

2247 Johannes Becker and Clemens Fuest, Tax Competition - Greenfield Investment versus Mergers and Acquisitions, March 2008

2248 Giorgio Bellettini and Hubert Kempf, Why not in your Backyard? On the Location and Size of a Public Facility, March 2008

2249 Jose Luis Evia, Roberto Laserna and Stergios Skaperdas, Socio-Political Conflict and Economic Performance in Bolivia, March 2008

2250 Bas Jacobs and A. Lans Bovenberg, Optimal Taxation of Human Capital and the Earnings Function, March 2008 
2251 Jan-Egbert Sturm and Timo Wollmershäuser, The Stress of Having a Single Monetary Policy in Europe, March 2008

2252 Guido Schwerdt, Labor Turnover before Plant Closure: 'Leaving the Sinking Ship' vs. 'Captain Throwing Ballast Overboard', March 2008

2253 Keith E. Maskus and Shuichiro Nishioka, Development-Related Biases in Factor Productivities and the HOV Model of Trade, March 2008

2254 Jeremy Edwards and Sheilagh Ogilvie, Contract Enforcement, Institutions and Social Capital: the Maghribi Traders Reappraised, March 2008

2255 Imed Drine and Christophe Rault, Purchasing Power Parity for Developing and Developed Countries. What can we Learn from Non-Stationary Panel Data Models?, March 2008

2256 Scott Alan Carson, Health, Wealth and Inequality: a Contribution to the Debate about the Relationship between Inequality and Health, March 2008

2257 C.A.E. Goodhart, The Regulatory Response to the Financial Crisis, March 2008

2258 Stefan Bauernschuster, Oliver Falck and Stephan Heblich, The Impact of Continuous Training on a Firm's Innovations, March 2008

2259 Michael Grimm and Stephan Klasen, Geography vs. Institutions at the Village Level, March 2008

2260 Fwu-Ranq Chang, Property Insurance, Portfolio Selection and their Interdependence, March 2008

2261 J. Atsu Amegashie and Marco Runkel, The Paradoxes of Revenge in Conflicts, March 2008

2262 Hans Jarle Kind, Marko Koethenbuerger and Guttorm Schjelderup, Efficiency Enhancing Taxation in Two-sided Markets, March 2008

2263 M. Hashem Pesaran, Til Schuermann and L. Vanessa Smith, Forecasting Economic and Financial Variables with Global VARs, March 2008

2264 Volker Grossmann, Entrepreneurial Innovation and Sustained Long-run Growth without Weak or Strong Scale Effects, March 2008

2265 Robert S. Chirinko and Huntley Schaller, The Irreversibility Premium, March 2008 